\title{
Near-Surface Density Currents Observed in the Southeast Pacific Stratocumulus-Topped Marine Boundary Layer*
}

\author{
MATt C. WilbanKS AND SANDRA E. YUTER \\ North Carolina State University, Raleigh, North Carolina \\ SIMON P. DE SZOEKE \\ Oregon State University, Corvallis, Oregon \\ W. AlAN BREWER \\ NOAA/Earth System Research Laboratory, Boulder, Colorado \\ Matthew A. Miller AND ANDrew M. Hall \\ North Carolina State University, Raleigh, North Carolina \\ CASEy D. BuRleyson \\ North Carolina State University, Raleigh, North Carolina, and Pacific Northwest National \\ Laboratory, Richland, Washington
}

(Manuscript received 24 October 2014, in final form 30 April 2015)

\begin{abstract}
Density currents (i.e., cold pools or outflows) beneath marine stratocumulus clouds are characterized using 30 days of ship-based observations obtained during the 2008 Variability of American Monsoon Systems (VAMOS) Ocean-Cloud-Atmosphere-Land Study Regional Experiment (VOCALS-REx) in the southeast Pacific. An air density increase criterion applied to the Improved Meteorological (IMET) sensor data identified 71 density current front, core (peak density), and tail (dissipating) zones. The similarity in speeds of the mean density current propagation speed $\left(1.8 \mathrm{~m} \mathrm{~s}^{-1}\right)$ and the mean cloud-level advection relative to the surface layer wind $\left(1.9 \mathrm{~m} \mathrm{~s}^{-1}\right)$ allowed drizzle cells to deposit elongated density currents in their wakes. Scanning Doppler lidar captured prefrontal updrafts with a mean intensity of $0.91 \mathrm{~m} \mathrm{~s}^{-1}$ and an average vertical extent of $800 \mathrm{~m}$. Updrafts were often surmounted by low-lying shelf clouds not connected to the overlying stratocumulus cloud. The observed density currents were 5-10 times thinner and weaker than typical continental thunderstorm cold pools. Nearly $90 \%$ of density currents were identified when C-band radar estimated areal average rain rates exceeded $1 \mathrm{~mm}_{\text {day }}{ }^{-1}$ over a $30-\mathrm{km}$ diameter. Rather than peaking when rain rates were highest overnight, density current occurrence peaks between 0600 and 0800 local solar time when enhanced local drizzle co-occurred with shallow subcloud dry and stable layers. The dry layers may have contributed to density current formation by enhancing subcloud evaporation of drizzle. Density currents preferentially occurred in a large region of predominantly open cells but also occurred in regions of closed cells.
\end{abstract}

\footnotetext{
* Supplemental information related to this paper is available at the Journals Online website: http://dx.doi.org/10.1175/MWR-D-14-00359.s1.

Corresponding author address: Matt C. Wilbanks, Department of Marine, Earth, and Atmospheric Sciences, North Carolina State University, Box 8208, Raleigh, NC 27695.

E-mail: mcwilban@ncsu.edu
}

\section{Introduction}

Cold, dense, near-surface density currents (also known as gravity currents, cold pools, or precipitationgenerated outflows) have recently been observed by aircraft beneath drizzling marine stratocumulus (Jensen et al. 2000; Terai and Wood 2013). Results from largeeddy simulations and cloud-system-resolving models 


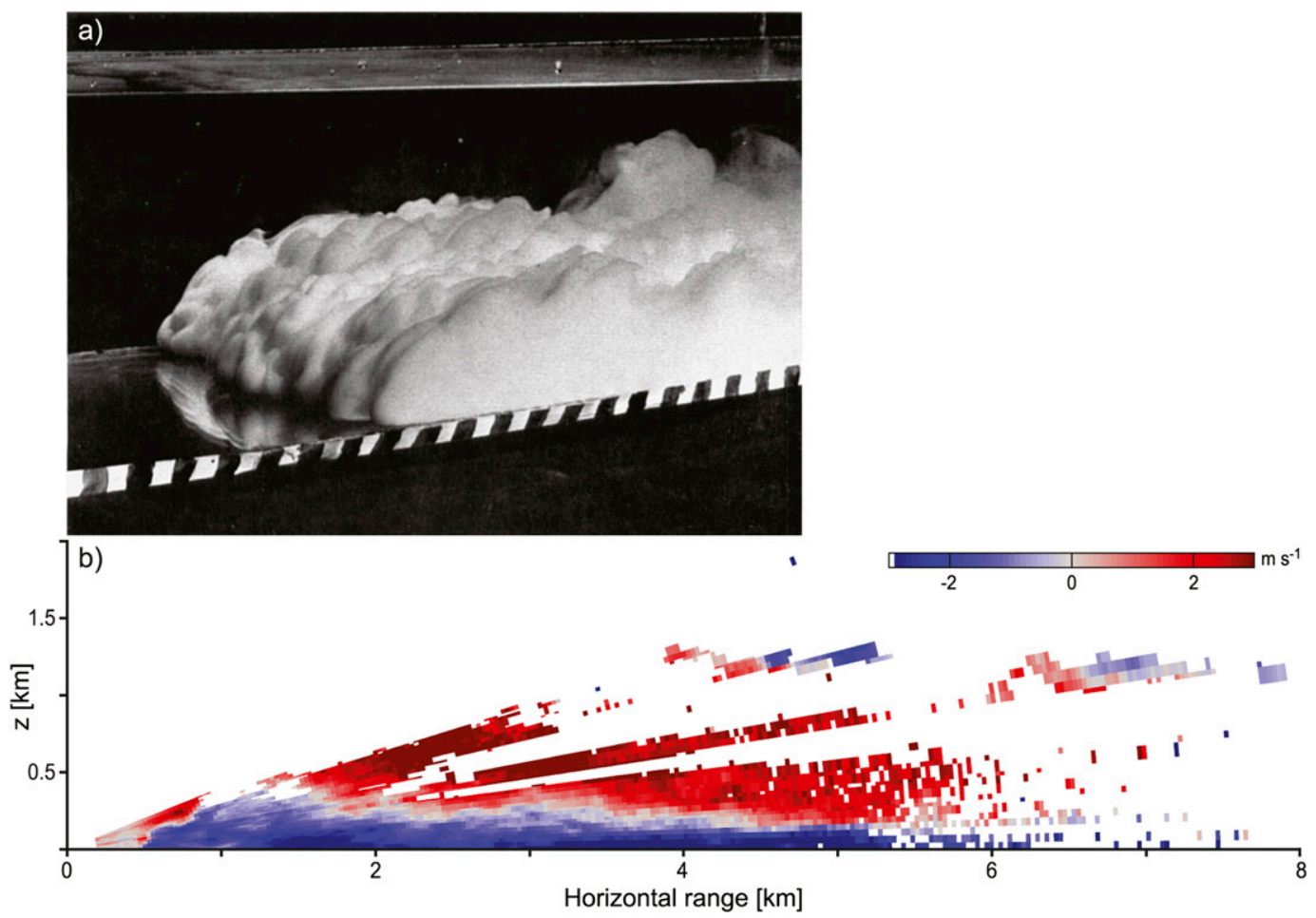

FIG. 1. (a) Example of a laboratory density current composed of white-colored saline solution propagating right-to-left in a channel of water (from Simpson 1969). The black and white strip at the bottom of the tank is marked at 1-cm intervals. (b) Doppler lidar RHI through a density current observed at 0824 UTC 26 Oct 2008 showing mean wind corrected radial velocity along a plane approximately orthogonal to the frontal boundary. Negative velocities (blue) indicate flow toward the ship located at the origin, and positive velocities (red) indicate flow away from the ship. The frontal boundary of the density current is located at the surface at $\approx 0.5$-km horizontal range and slants backward with height up to the depth of the head $(\approx 400 \mathrm{~m})$ near 1-km range.

suggest that density currents may be a driver of mesoscale organization in drizzling marine stratocumulus convection (Savic-Jovcic and Stevens 2008; Wang and Feingold 2009; Feingold et al. 2010; Wang et al. 2010; Berner et al. 2011; Kazil et al. 2014). In this study, we present shipboard measurements of density currents during the Variability of American Monsoon Systems (VAMOS) Ocean-Cloud-Atmosphere-Land Survey Regional Experiment (VOCALS-REx; Wood et al. 2011a; Mechoso et al. 2014) in the southeast Pacific (SEP). The combination of ship-based scanning and in situ observations permits an examination of density current phenomenology within the context of the evolving mesoscale cloud and precipitation structures.

Density currents occur in the atmosphere when cooler, negatively buoyant air descends to the surface, diverges, and propagates radially into the surrounding boundary layer. The dynamics that drive density current flows are very similar throughout a broad spectrum of interactions between fluids of different densities. The kinematic structure and evolution of density currents have been described extensively in both laboratory and observational settings (Simpson 1997). Figure 1 illustrates a number of key kinematic features. The density current propagates horizontally along a sharp and well-defined frontal boundary. The front undercuts and accelerates the less dense prefrontal fluid, which is drawn up and backward in a so-called return circulation overtop and behind the deepest part (or "head") of the density current. The density current depth tapers off in the "tail." Turbulent "billows" are often generated by Kelvin-Helmholtz instability due to vertical shear along the top of the density current.

Evaporative cooling and precipitation loading can generate downdrafts and subsequent outflows (Srivastava 1987). Outflows generated by deep convection have been the subject of numerous studies, particularly in midlatitude continental environments (e.g., Charba 1974; Goff 1976; Wakimoto 1982; Wilson and Schreiber 1986; Droegemeier and Wilhelmson 1987; Mahoney 1988; Engerer et al. 2008). Samples of cold pool intensities from these studies vary from about 2 to $10 \mathrm{~K}$ over depths of 1.4 to $4 \mathrm{~km}$, with prefrontal updrafts of at least $5-10 \mathrm{~m} \mathrm{~s}^{-1}$ (Charba 1974; Goff 1976; Wakimoto 1982; Bryan et al. 2007; Engerer et al. 2008). Outflows have also been described in studies of 
deep convection over tropical oceans (e.g., Houze 1977; Zipser 1977; Gamache and Houze 1982) and shallow marine precipitating trade cumulus (Warner et al. 1979; Snodgrass et al. 2009; Nuijens et al. 2009; Zuidema et al. 2012; Seifert and Heus 2013).

Subtropical marine stratocumulus clouds in the SEP are confined within the boundary layer by a strong capping inversion between about 1000 and $1500 \mathrm{~m}$ altitude (de Szoeke et al. 2012). The limited cloud thickness constrains the intensity of precipitation and thus the size and intensity of precipitation-generated density currents and their associated temperature perturbations. Although substantially weaker than their deep convective counterparts, drizzle-driven density currents are proposed to influence the marine stratocumulus mesoscale circulations in several ways (Savic-Jovcic and Stevens 2008; Wang and Feingold 2009; Wang et al. 2010; Feingold et al. 2010; Berner et al. 2011; Kazil et al. 2014). Mechanical lifting along the outflow frontal boundary is associated with the formation of shelf clouds or mesoscale arcs (Zuidema et al. 2012; Jensen et al. 2000). In the case of squall lines, the depth of the leading edge lifting is a function of the balance between cold pool strength and ambient shear (Weisman and Rotunno 2004). Lifting is more intense and extends higher when two outflows collide and is most effective at generating convection when the two outflows collide headon (Wilson and Schreiber 1986; Wakimoto and Kingsmill 1995; Harrison et al. 2009; Feingold et al. 2010). Additionally, convective activity is suppressed within the outflow as a result of increased static stability and near-surface divergence (Stevens 2000; Savic-Jovcic and Stevens 2008; Feingold et al. 2010; Berner et al. 2011).

Data obtained by aircraft provide valuable information along a line (for in situ measurements) or curtain (for vertically pointing measurements). Two aircraft studies of marine stratocumulus cold pools have provided basic structural and thermodynamic statistics and some insight into how density currents affect the cloud field. Terai and Wood (2013) composited flight data obtained at $150 \mathrm{~m}$ altitude by the National Center for Atmospheric Research (NCAR) C-130 aircraft during VOCALS-REx and used a temperature drop criteria to identify the boundaries of 80 cold pools. The cold pools were on average $0.4 \mathrm{~K}$ cooler and $0.45 \mathrm{~g} \mathrm{~kg}^{-1}$ moister than the surroundings. Jensen et al. (2000) presented flight legs taken beneath a closed cell marine stratocumulus region west of Tasmania during the Southern Ocean Cloud Experiment. They found precipitating $\left(\approx 5 \mathrm{~mm} \mathrm{day}^{-1}\right)$, low-lying arc clouds directly above the frontal boundaries of drizzleinduced cold pools. The arc clouds appeared to be connected to the overlying stratocumulus deck.

The combination of scanning and in situ ship-based observations during VOCALS-REx allows us to address previously unexplored aspects of density current phenomenology and their evolution, including the diurnal cycle of density current occurrence; the proximity to evolving two-dimensional mesoscale cloud and drizzle features; the boundary layer profiles of moisture, shear, and stability both inside and outside density currents; and the density current flow structure and shape. The dataset includes the first scanning Doppler lidar depictions of SEP density currents, their prefrontal updrafts, and associated cloud formations. We use these data to examine the potential role of density currents in modulating marine stratocumulus mesoscale cloud organization.

\section{Data and methods}

\section{a. Datasets}

During VOCALS-REx, the National Oceanic and Atmospheric Administration (NOAA) research ship the Ronald H. Brown (RHB) served as an instrument platform for observations of the marine boundary layer (de Szoeke et al. 2010; Wood et al. 2011a; Mechoso et al. 2014). An array of instruments on board collected 30 days of data on cloud, precipitation, and aerosol; near-surface winds and meteorological variables; and boundary layer properties while transecting the SEP near $20^{\circ} \mathrm{S}$ between $71^{\circ}$ and $85^{\circ} \mathrm{W}$ (de Szoeke et al. 2012, their Fig. 1).

\section{1) SCANNING HIGH-RESOLUTION DOPPLER LIDAR}

The NOAA high-resolution Doppler lidar (HDRL; Grund et al. 2001) was programmed to cycle through upward-pointing, plan position indicator (PPI), and range height indicator (RHI) volume coverage patterns (VCP) approximately every $20 \mathrm{~min}$, spending approximately half the time in upward-pointing mode. RHI scans were conducted at right angles to one another but with otherwise variable azimuth headings. Generally, 1 RHI scan spanned $0^{\circ}-25^{\circ}$ in elevation over $\approx 30 \mathrm{~s}$. One or two $1^{\circ}$ elevation PPI scans (covering $0^{\circ}-360^{\circ}$ azimuths in $\approx 3 \mathrm{~min}$ ) were usually performed every $\mathrm{VCP}$ cycle. One PPI scan per cycle was conducted at higher elevation angles $\left(4^{\circ}-25^{\circ}\right)$ to capture the mean wind profile in a manner suitable for velocity-azimuth display (VAD) analysis (Browning and Wexler 1968). The polar coordinate RHI, PPI, and upward-pointing scan volumes were separated from hourly files, and the resulting arrays were converted from spherical to Cartesian coordinates for further analysis. Details of the instrument are presented in appendix A.

Lidar backscatter intensity data from this instrument should not be viewed as an absolute measurement because of path-integrated constraints on signal intensity (see appendix A). Following Tucker et al. (2009), we make qualitative interpretations of backscatter intensity 
gradients over limited time frames. Differences in backscatter intensity between range gates are primarily determined by the combined effect of particle size and number on the backscatter coefficient $(\beta)$ of the scattering volume. The lidar preferentially detects particles whose diameters $(D)$ are in the Mie scattering regime $(D \approx \lambda$, where $\lambda$ is lidar wavelength; Feingold and Grund 1994)primarily aerosols. For spherical particles, $\beta$ is proportional to the second moment of the size distribution $N(D) D^{2}$, where $N$ is number concentration (Intrieri et al. 1993; Cairo et al. 2011). However, because of the resonance behavior of Mie scatterers, the relationship between the size of a particle and its backscatter coefficient is not monotonic.

Water uptake by hygroscopic aerosol in moist air results in particle growth and larger particle scattering coefficients (Tang 1996). The majority of the aerosols observed in the SEP boundary layer is hygroscopic (i.e., sulfate, sea salt, and nitrates) (Allen et al. 2011; Shank et al. 2012). Hence, regions of lower backscatter intensity have an ambiguous interpretation as they could contain locally lower aerosol concentrations and/or locally lower relative humidity $(\mathrm{RH})$.

\section{2) AdDitional InStruments}

Ship-relative winds, temperature, pressure, and humidity were measured at $1 \mathrm{~Hz}$ using the Improved Meteorological (IMET) sensors (Colbo and Weller 2009) onboard the $R H B$ and discretely averaged over 1-min intervals. Winds were corrected for ship heading, speed, pitch, roll, and yaw to derive the true winds. Median, 15th, and 85th percentiles of cloud-base height were calculated over 10-min intervals from Vaisala lidar ceilometer retrievals (de Szoeke et al. 2010). A full discussion of the method used to derive rain rates for the cruise is presented in Burleyson et al. (2013). The rain rates used in this study, which we hereafter refer to as cloud-base rain rates or simply $R$, follow the definition used in Comstock et al. (2004). We also use retrieved integrated cloud liquid water path to detect drizzle directly over the ship (Zuidema et al. 2012; Painemal and Zuidema 2011). Geostationary Operational Environmental Satellite (GOES) visible (VIS) and infrared (IR) satellite data provide context on the mesoscale cloud field. The satelliteIR-derived cloud fraction used in this study was described in Burleyson and Yuter (2015a). We use the RHB C-band radar reflectivity data (Ryan et al. 2002) to provide information on the spatial distribution, evolution, and cloudbase areal average rain rates of drizzle cells in the vicinity of the ship (Burleyson et al. 2013). The methods used to obtain the drizzle cell tracking statistics presented in this study are provided in Hall (2013).

A Vaisala RS92 rawinsonde was launched from the ship every $4 \mathrm{~h}$. Profiles of temperature, pressure, and relative humidity were used to derive virtual potential temperature $\left(\theta_{v}\right.$; Lilly 1968). The dry Brunt-Väisälä frequency ( $N$; Stull 1988) was calculated for the subcloud boundary layer from the lowest 100-m layer (at the surface) to the 100-m layer just beneath the median cloud base.

\section{b. Feature identification and classification of density currents from in situ ship data}

The periods used to identify density currents were obtained during both legs of the VOCALS-REx cruise and spanned from 0000 UTC 24 October to 0600 UTC 3 November 2008 and from 0000 UTC 11 November to 0000 UTC 30 November 2008 ( 30 days and 6h). By selecting these periods, we removed unphysical values in the ship air pressure time series collected on 3 and 10 November 2008. As part of the quality control of the time series data, we removed periods when there was potential for the instruments at the ship's bow to be contaminated by ship exhaust following Bates et al. (2008). These were periods when the ship-relative winds were more than $60^{\circ}$ off the ship's bow or the shiprelative wind speed was less than $3 \mathrm{~m} \mathrm{~s}^{-1}$.

During VOCALS-REx, the RHB's course and heading varied over time. The ship had periods when it held station and other periods with cruising speeds up to $\approx 6 \mathrm{~m} \mathrm{~s}^{-1}$. Observed wind speeds were $1-14 \mathrm{~m} \mathrm{~s}^{-1}$, and wind direction was usually from the southeast. To examine the shape and extent of density currents and their features in a common frame of reference, we calculated ship-relative displacement by discretely integrating the 1-min ship-relative wind speed. All data series were then linearly interpolated along a regularly spaced shiprelative wind displacement vector with $100-\mathrm{m}$ spacing. Finally, to smooth high-frequency variations, which tended to interfere with density current identification, we calculated the $3.5-\mathrm{km}$, simple, unweighted, moving window average of air density.

Figure 2 shows the complete set of criteria for finding density current feature points on an example segment of the ship air density series $(\rho)$. Each of the 71 density currents is identified by the detection of a sustained increase in ship air density as its front passes over the ship, specifically a $1 \mathrm{~g} \mathrm{~m}^{-3}$ increase in the $3.5-\mathrm{km}$ moving window average of air density $(\bar{\rho})$. The criterion corresponds to an increase in density of $\approx 0.083 \%$, which is equivalent to a cold pool of intensity of $\approx 0.24 \mathrm{~K}$ at $T=$ $290 \mathrm{~K}$ assuming constant specific humidity (Terai and Wood 2013). Contiguous data points meeting this criterion are combined into a single density current front. The start time of the density current-as determined by the ship temperature series and lidar wind field—can be offset from the start of the density increase by up to 


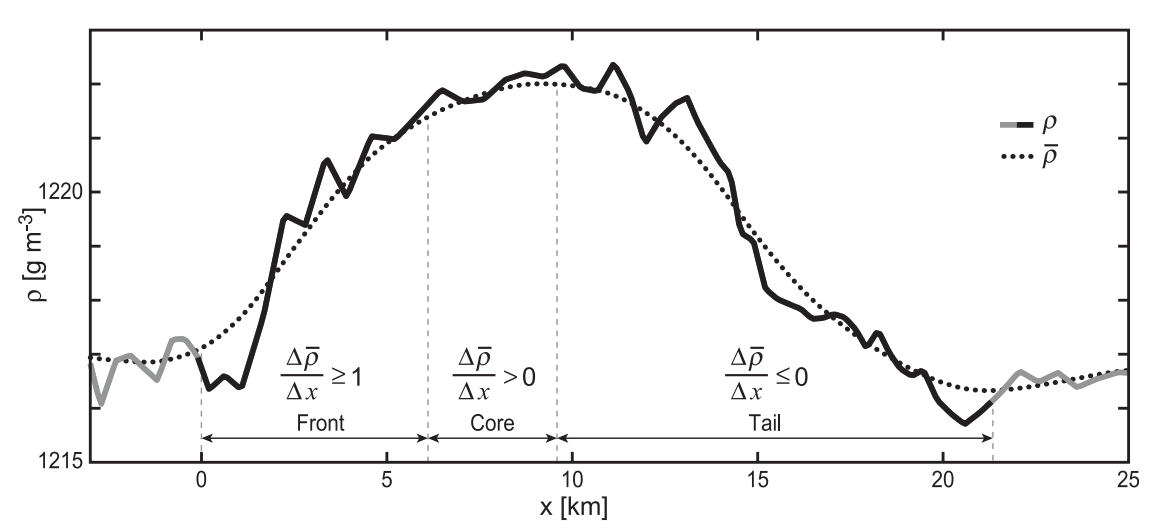

FIG. 2. Example of a phenomenon in the ship air density 100-m ship-relative displacement data series ( $\rho$, solid gray) that was identified by the density current algorithm (highlighted in solid black). The origin of the ship-relative displacement axis $(x)$ is set to the start of the density current front. The $3.5-\mathrm{km}$ moving window average of air density $(\bar{\rho})$ is shown with the dotted black line. Dashed vertical lines mark the intervals over which the density current front, front/ core, and tail zones were defined using the slope criteria of $\bar{\rho}$ summarized above the $x$ axis.

3 min because the $\bar{\rho}$ series tends to deviate from $\rho$ before the start of the density current front. We therefore adjusted the start times of each density current by eye.

Density currents often display signature features in the air density data series. The density current front is followed by a plateau of approximately peak density, which we refer to as the density current "core." The density current core starts with the first data point that no longer satisfies the frontal zone slope criteria and ends when the slope of $\bar{\rho}$ first becomes negative after the density current front. After the density core has passed over the ship, density decreases, and this is the region we refer to as the density current tail. The density current tail ends where the slope of $\bar{\rho}$ first becomes positive after the density current core. It was often the case that RHI lidar scans and lidar VADs through our tail zones indicated shallower layers of perturbed flow compared to the preceding front and core zone.

\section{Results}

\section{a. Cloud structures above density current frontal boundaries}

Daytime cloud photographs taken from the deck of the ship illustrate density current horizontal structure, associated cloud features, and the configuration of density currents in relation to proximate source drizzle cells. Figure 3 a shows a panoramic image taken of an isolated drizzle cell in an open-cellular region as it passed by the ship in the early morning at $\approx 1205$ UTC [0625 local time (LT)] on 27 October 2008 [cf. isolated cells in Comstock et al. (2007, their Figs. 1c,d)]. This drizzle cell spans at least $20 \mathrm{~km}$ in the radar domain to the north and east of the ship (Fig. 3b). This particular drizzle cell was observed entering the radar domain starting at 1012 UTC, nearly $2 \mathrm{~h}$ before Fig. 3a was taken, and was observed to dissipate at 1245 UTC. Over the $\approx 2.5 \mathrm{~h}$ that this drizzle cell was observed in the domain, it reached a maximum intensity of $Z=42 \mathrm{dBZ}$ and maintained a median area of $147 \mathrm{~km}^{2}$. The overlaid lidar PPI radial velocity data show the density current frontal boundary approaching from due east at a $4-\mathrm{km}$ range from the ship. The density current frontal boundary appears to radiate from a point $5 \mathrm{~km}$ to the southeast of the most intensely drizzling region associated with this cell at 1201 UTC.

The cloud field in Fig. 3a implies a complex drizzle cell structure. Southward from the most intensely drizzling region (bracket A), an anvil-shaped cloud radiates beneath the inversion near the top of the cell. This feature is detected as a broad and diffuse region of less intense precipitation in the radar. Clouds with locally lower cloud bases surround the most intense drizzling region to the north and east of the ship (bracket A). Above and directly in front of the density current frontal boundary to the east of the ship, there are clouds in three separate layers. From top to bottom are the main layer of stratocumulus clouds, midboundary layer clouds (bracket B), and lower altitude clouds immediately over top of the main density current flow (bracket $\mathrm{C}$ ). The midboundary layer cloud extends at least $10 \mathrm{~km}$ south of the most intensely drizzling region, consistent with a cold pool centered southeast of the source drizzle cell.

Rawinsonde profiles of $\theta_{v}, \mathrm{RH}$, and water vapor mixing ratio $\left(q_{v}\right)$ observed in the boundary layer $\approx 40 \mathrm{~min}$ prior to the panorama (Fig. $3 \mathrm{a}$ ) are shown in Fig. 3c. The sounding data are useful for examining key thermodynamic variables related to boundary layer 


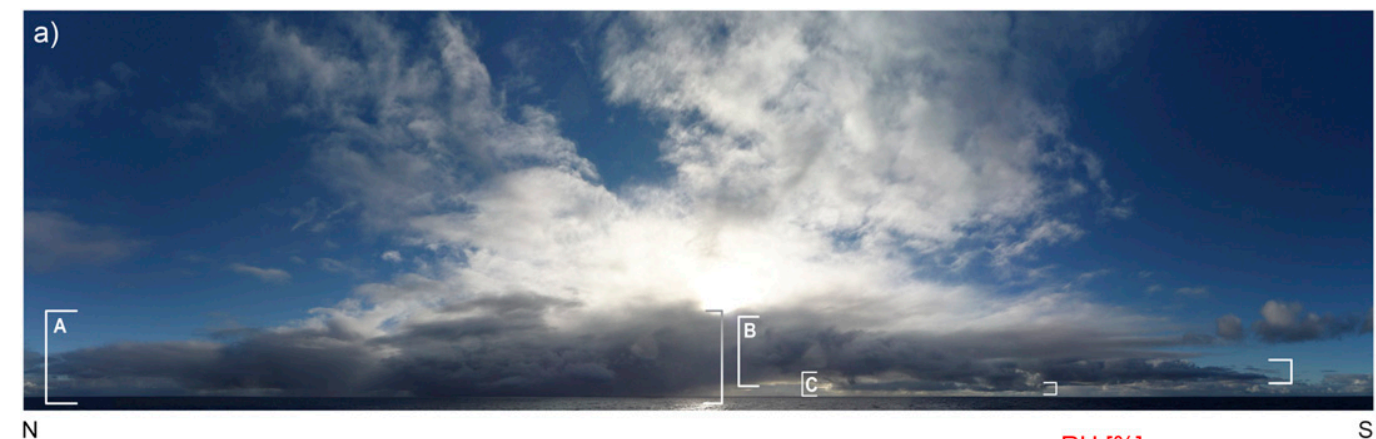

$\mathrm{N}$
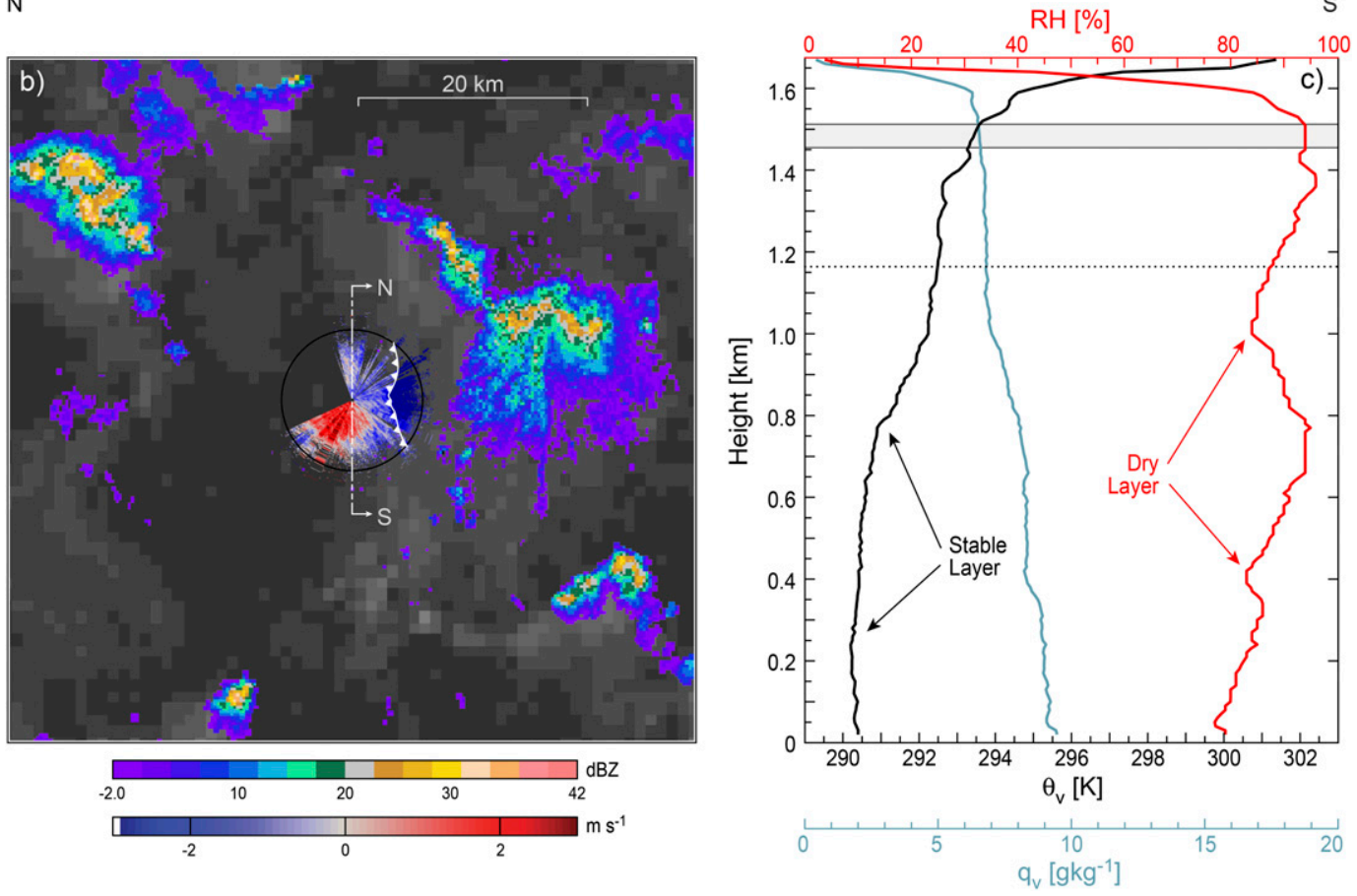

FIG. 3. (a) Panoramic photograph taken across the bow of the ship from north (left edge) to south (right edge) at $\approx 1205$ UTC 27 Oct 2008 . A density current crossed the ship from the east-southeast at 1213 UTC. White brackets frame cumulus formations in the middle and low levels of the boundary layer (see text). (b) Corresponding GOES VIS image (1145 UTC), shipboard C-band radar reflectivities (1203 UTC), and shipboard lidar PPI of 8-h moving window average mean wind corrected radial velocity (1201 UTC) superimposed within a 6-km range (black circle) of the ship. The white section line indicates the field of view of (a). The density current frontal boundary is marked in white over the lidar PPI. The grayscale of the satellite image has been modified to enhance the clouds in this low sun angle image. (c) Boundary layer $\theta_{v}$ (black), RH (red), and $q_{v}$ (light blue) profiles collected via rawinsonde released at 1121 UTC 27 Oct 2008. Profiles are averaged over 30-m vertical intervals. The gray horizontal band indicates the cloud layer bound by the 10-min average median ceilometer cloud base estimate and the soundingderived inversion height (cloud top). The horizontal dotted line is the 15 th percentile of ceilometer cloud base hits, representing a lower bound on the cloud base estimate. Arrows point to the approximate altitude of subcloud stable layers and dry layers.

coupling. They are, however, single profile measurements, and the degree of coupling in the marine stratocumulustopped boundary layer can vary on the mesoscale (Nucciarone and Young 1991; Comstock et al. 2005). The profiles $\theta_{v}$ and RH display the signature of a less coupled boundary layer, which manifests in the presence of one or more subcloud stable layers of increasing $\theta_{v}$ with height that separate layers of approximately equal $\theta_{v}$. In Fig. $3 \mathrm{c}$, the stable layers are located between 250 and $400 \mathrm{~m}$ altitude $\left(\Delta \theta_{v} \approx 0.25 \mathrm{~K}\right)$ and between 775 and $1000 \mathrm{~m}$ altitude $\left(\Delta \theta_{v} \approx 1.5 \mathrm{~K}\right)$. The RH profile exhibits local minima (i.e., drier layers) at the tops of the two stable layers. Subcloud stable layers inhibit upward turbulent transport of surface-based moisture, resulting in decreasing $q_{v}$ with height through the stable layer (Nicholls 1984; Albrecht et al. 1995; Bretherton 1997; 

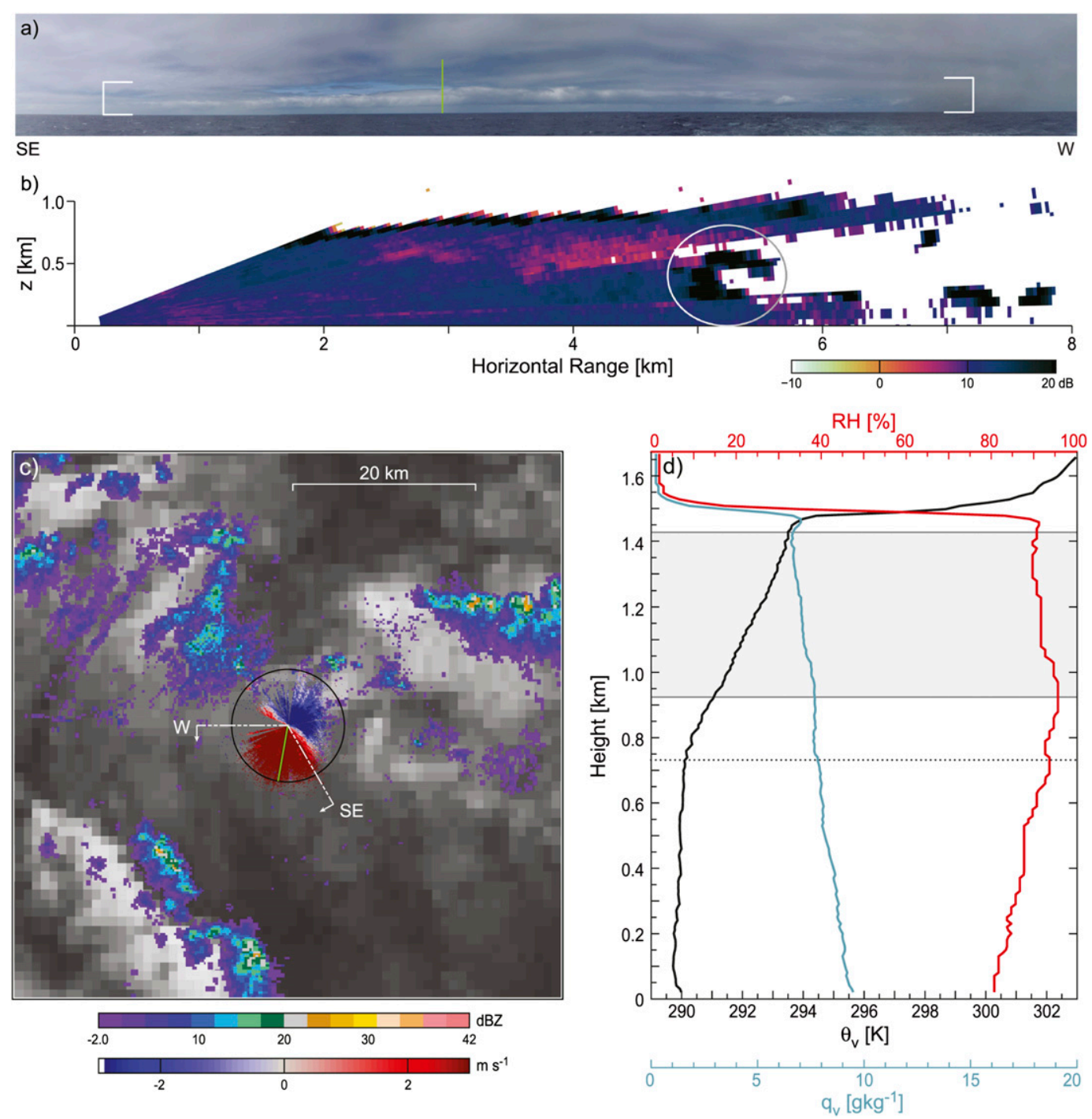

FIG. 4. (a) Panoramic photographs taken from the southeast (left) to the west (right) at $\approx 1605$ UTC 28 Oct 2008. The white brackets frame the shelf cloud seen along and directly above the density current front that approached from the east and southeast and crossed the ship $\approx 25$ min earlier at 1541 UTC. (b) Lidar backscatter RHI taken from inside the density current (1544 UTC) transecting the shelf cloud (gray circle) at $190^{\circ}$ azimuth [marked also with the vertical green line in (a) and the southward-pointing one in (c)]. (c) Corresponding GOES VIS (1558 UTC), lidar PPI (1603 UTC), and C-band radar (1603 UTC) as in Fig. 3b. The density current frontal boundary is not present in the lidar domain. (d) Thermodynamic profiles from rawinsonde released at 1526 UTC 28 Oct 2008, as in Fig. 3c. No stable layers or dry layers are present in the sounding.

Comstock et al. 2005; Jones et al. 2011; Burleyson et al. 2013).

Figure 4 shows a panoramic photo facing south and west (Fig. 4a) of a shelf cloud above the frontal zone of a density current. This image was taken $\approx 25 \mathrm{~min}$ after the front crossed the ship from the east and southeast at 1541 UTC (1010 LT) on 28 October 2008. This configuration puts the ship within the density current tail zone (see Fig. 2), from which the ship emerges at 1618 UTC $(\approx 13 \mathrm{~min}$ after Figs. 4a,c). The lidar PPI of velocity (Fig. 4c) indicates a northeasterly wind flow across the domain (no fronts in lidar range). The source drizzle cell is located between 6 and $20 \mathrm{~km}$ range to the northwest of the ship in Fig. $4 \mathrm{c}$ and is not in the field of view of the cloud photo in Fig. 4a. The source drizzle cell was tracked entering the radar domain starting $\approx 75 \mathrm{~min}$ (1448 UTC) prior to Fig. 4a and was observed to dissipate $\approx 20 \mathrm{~min}$ (1627 UTC) after Fig. 4a. Over the $\approx 1.5 \mathrm{~h}$ that this drizzle cell was observed in the domain, it reached a maximum intensity of $Z=33 \mathrm{~dB} Z$ and had a median area of $62 \mathrm{~km}^{2}$. 


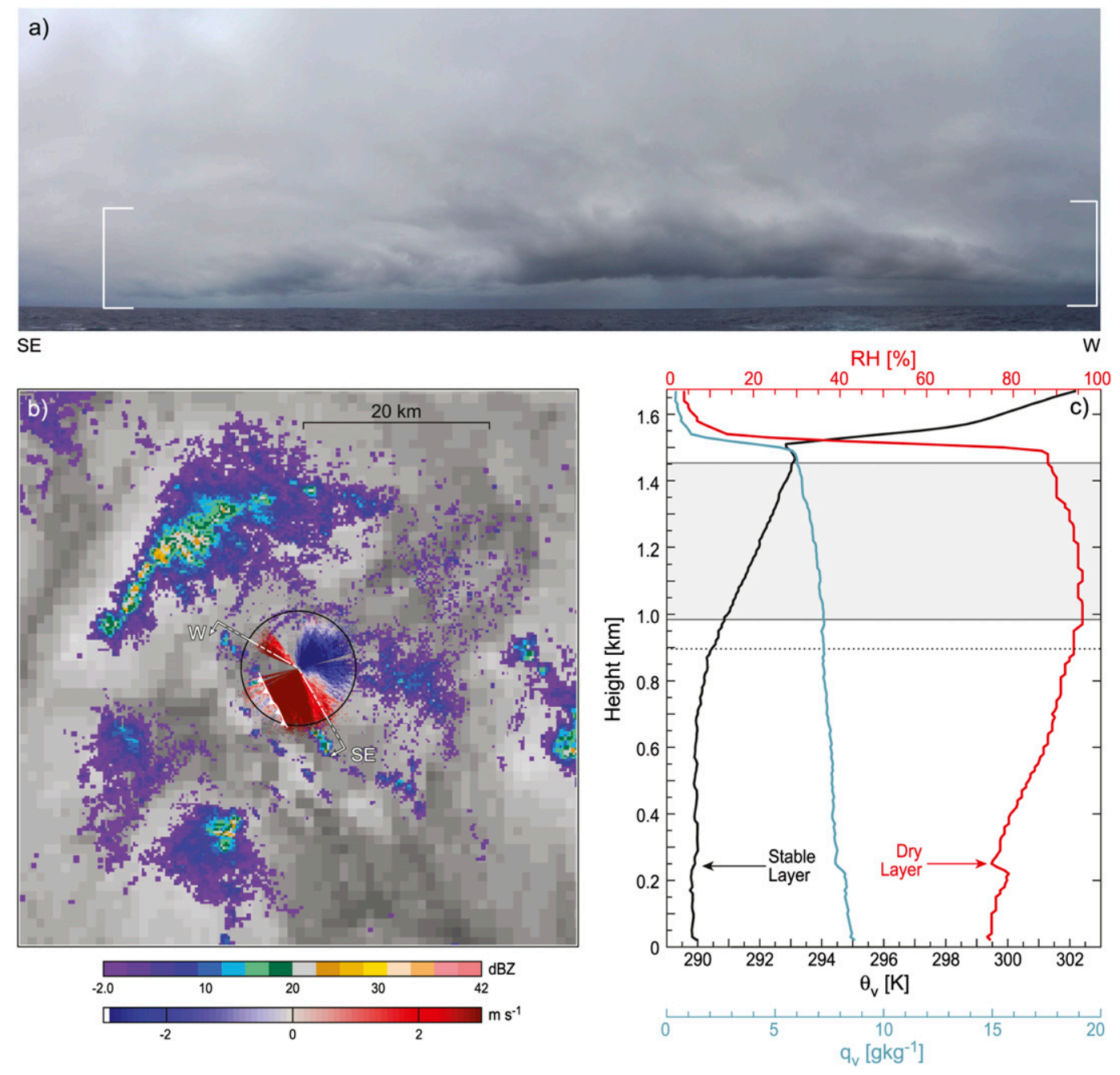

FIG. 5. (a) Panoramic photographs taken from the southeast (left) to the northwest (right) at $\approx 1405$ UTC 29 Oct 2008. The white brackets frame the shelf cloud seen along and directly above the density current front that approached from the east and crossed the ship at 1353 UTC. (b) Corresponding GOES VIS satellite (1358 UTC), radar (1403 UTC), and lidar PPI (1400 UTC) as in Fig. 3b. (c) Thermodynamic profiles from rawinsonde released at 1526 UTC 29 Oct 2008, as in Fig. 3c.

Like the midboundary layer shelf cloud seen in Fig. 3a (bracket B), the shelf cloud in Fig. 4a extends at least $10 \mathrm{~km}$ behind (southeast of) the source drizzle cell. The lidar RHI scan collected 3 min after the front crossed the ship (Fig. 4b) shows a cross section at $190^{\circ}$ azimuth within the density current. At that time, the top of the shelf cloud is separated from overlying stratocumulus deck by at least $200 \mathrm{~m}$. Vertical profiles of $\theta_{v}, q_{v}$, and RH observed in the boundary layer $\approx 40 \mathrm{~min}$ prior to the panorama in Fig. 4a are shown in Fig. 4d. Consistent with a less coupled boundary layer, $\theta_{v}$ increases by $\approx 1 \mathrm{~K}$ from the surface to the median cloud base. Stable, drier layers as shown in Fig. 3c are not apparent in the profiles in Fig. 4c.

The situation depicted in Fig. 5 illustrates a density current that crossed the ship at 1353 UTC (0845 LT)
29 October 2008 within a region of high cloud fraction and a complex, inconstant, and tightly clustered drizzle cell field. Within the lidar domain (Fig. 5b), there is a convergent boundary in the southwest quadrant. This convergence line corresponds to a portion of the front of the density current, which moves across the domain from the northeast. In addition, the panoramic photo shows a drizzling shelf cloud corresponding to a northwestsoutheast line of small echoes (near arrow labeled SE in the figure) in the sequence of C-band radar data (not shown). Figure $5 \mathrm{c}$ shows the most proximate rawinsonde profiles of $\theta_{v}$ and $\mathrm{RH}$, which were sampled $\approx 80 \mathrm{~min}$ after the cloud photo panorama (Fig. 5c). A stable layer topped with a subcloud RH minimum is located between 250 and $300 \mathrm{~m}$ altitude $\left(\Delta \theta_{v} \approx 0.25 \mathrm{~K}\right)$, and $\theta_{v}$ increases 
TABLE 1. Statistics describing observed density currents. Variables shown are density current temperature depression $\left(\Delta T_{\text {front }+ \text { core }}\right)$; estimated depth $(h)$ from lidar VADs $(N=34)$; density current length along time-integrated ship transects $(L)$; duration of density current in ship time series $(t)$; ratio of tail length to combined front and core length ( $\left.L_{\text {tail }}: L_{\text {front }+ \text { core }}\right)$; magnitude of the 10-min average wind vector immediately prior to the arrival of the density current $\left(\bar{U}_{\text {prefrontal }}\right)$; strength of the resultant wind anomaly inside density current front zones ( $\overline{U_{\text {frontzone }}^{\prime}}$ ); and maximum strength of the wind anomaly inside density current front and core zones $\left(U_{\max }^{\prime}\right)$. Wind anomalies are calculated with respect to $\bar{U}_{\text {prefrontal }}$.

\begin{tabular}{lccccc}
\hline \hline & & & \multicolumn{3}{c}{ Percentile } \\
\cline { 3 - 6 } & Range & Mean & 25 th & 50 th & 75 th \\
\hline$\Delta T_{\text {front }+ \text { core }}$ & $0.2-2.1$ & 0.8 & 0.6 & 0.8 & 1.0 \\
$h(\mathrm{~m})$ & $80-610$ & 330 & 230 & 310 & 400 \\
$L(\mathrm{~km})$ & $5-40$ & 15 & 9 & 14 & 20 \\
$t(\mathrm{~min})$ & $8-161$ & 33 & 16 & 29 & 40 \\
$L_{\text {tail }}: L_{\text {front }+ \text { core }}$ & $0.1-5.8$ & 1.6 & 0.8 & 1.5 & 2.4 \\
$\bar{U}_{\text {prefrontal }}\left(\mathrm{m} \mathrm{s}^{-1}\right)$ & $3.2-13.0$ & 8.4 & 6.5 & 8.2 & 10.4 \\
$U_{\text {frontzone }}^{\prime}\left(\mathrm{m} \mathrm{s}^{-1}\right)$ & $0.2-5.1$ & 1.8 & 1.0 & 1.7 & 2.4 \\
$U_{\text {max }}^{\prime}\left(\mathrm{m} \mathrm{s}^{-1}\right)$ & $1.1-8.1$ & 4.2 & 3.3 & 4.1 & 4.9 \\
\hline
\end{tabular}

by $\approx 0.9 \mathrm{~K}$ from the ocean surface to the median cloud base.

\section{b. Density current dimensions and strength}

Basic statistics on the distributions of density current size, strength, and shape are provided in Table 1. Our estimates of density current length along time-integrated ship transects $(L)$ range from 4 to $40 \mathrm{~km}$ and are inside the range of $0.6-171 \mathrm{~km}$ for cold pool diameters presented in Terai and Wood (2013). Density current depth $(h)$ was estimated from lidar VADs collected through the front or core of 34 density currents by locating the height where, after subtracting the prefrontal wind profile, the directional shear commenced above a layer of speed shear. This wind configuration indicates $h$ at the base of the density current return flow. Our mean depth $(\bar{h}=330 \mathrm{~m})$ agrees with Terai and Wood's (2013) estimate of $335 \mathrm{~m}$ using a different method. The sample duration $(t)$ is on average $33 \mathrm{~min}$ and is less than $1 \mathrm{~h}$ in more than $90 \%$ of density currents. Note that $L$ is strongly constrained by advection of density currents over the ship by the mean wind $\left(\bar{U}_{\text {prefrontal }}\right)$, indicated by the coefficient of determination $\left(r^{2}=0.82\right)$ between $\bar{U}_{\text {prefrontal }} \times t$ and $L$. The density current temperature depression $\left(\Delta T_{\text {front }+ \text { core }}\right)$ is the magnitude of the drop in temperature measured between the start of the density current and the end of the core zone $\left(\overline{\Delta T}_{\text {front }+ \text { core }}=0.8 \mathrm{~K}\right)$. The mean resultant wind anomaly inside the front zone ( $\left.\overline{U_{\text {frontzone }}^{\prime}}\right)$ is $1.8 \mathrm{~m} \mathrm{~s}^{-1}$. Both are approximately twice Terai and Wood's (2013) estimates. This discrepancy may exist because our method selects for larger cold pool frontal boundaries $(\Delta x \geq 3.5 \mathrm{~km})$ versus Terai and Wood's (2013) method $(\Delta x \geq 800$ $1200 \mathrm{~m})$.
Our estimate of observed density current propagation speed $\overline{U_{\text {frontzone }}^{\prime}}$ (Table 1 ) is based on the ship anemometer data. The limited domain of the lidar ( $\sim 6 \mathrm{~km}$ radius) and the scan strategy employed during VOCALS-REx precluded estimate of propagation speed based on tracking the locations of frontal boundaries as in Wakimoto (1982). The method used to evaluate our estimate of observed propagation speed compared to theoretical density current propagation speed is discussed in appendix B.

\section{c. Changes in ship meteorological variables across time-integrated ship transects through density currents}

Figure 6a plots the distribution of perturbations in ship-level air density before and during the passage of each density current over the ship. As a consequence of the method used to identify density currents (see section $2 b$ ), air density increases sharply across the front, begins to level off, reaches a maximum just prior to the end of the core zone, and then drops over the tail zone. The tail zone is elongated about the time-integrated ship transect and is characterized by more gradual changes in density compared to the front and core zone. Table 1 shows that tail zones are on average $\sim 60 \%$ longer than the combined front and core transects $\left(L_{\text {tail }}: L_{\text {front }+ \text { core }}\right)$. The average tail length is an underestimate since 27 density currents tail zones were terminated by a sharp increase in density (likely another density current). Eleven of these 27 tail zones were terminated by a density anomaly sufficiently large and persistent to be identified by our density current algorithm. This pattern is consistent with a planform of compounded and clustered outflows (Terai and Wood 2013; Kazil et al. 2014) in which tail zones tend to be curtailed by new, distinct outflow boundaries.

The differences in ship-relative displacement along ship transects through the combined front and core zones compared to the tail zones are not a consequence of our method. We confirmed this by applying the density current detection algorithm to the reverse time series of air density (not shown). If the time-integrated cold pools were symmetric, the end of the tail zone would correspond to a sharp density gradient, similar to what is observed for density current fronts. We do not see this in the majority of cases. Less than a third of cases in the reverse time series had fronts within $5 \mathrm{~km}$ of an identified forward time series tail zone end. Figures $6 \mathrm{~b}-\mathrm{d}$ display the perturbations of ship air temperature, vapor mixing ratio, and pressure plotted in the same manner as Fig. 6a.

The subset of 24 tail zones in which density perturbations were observed to fully rebound to prefrontal 


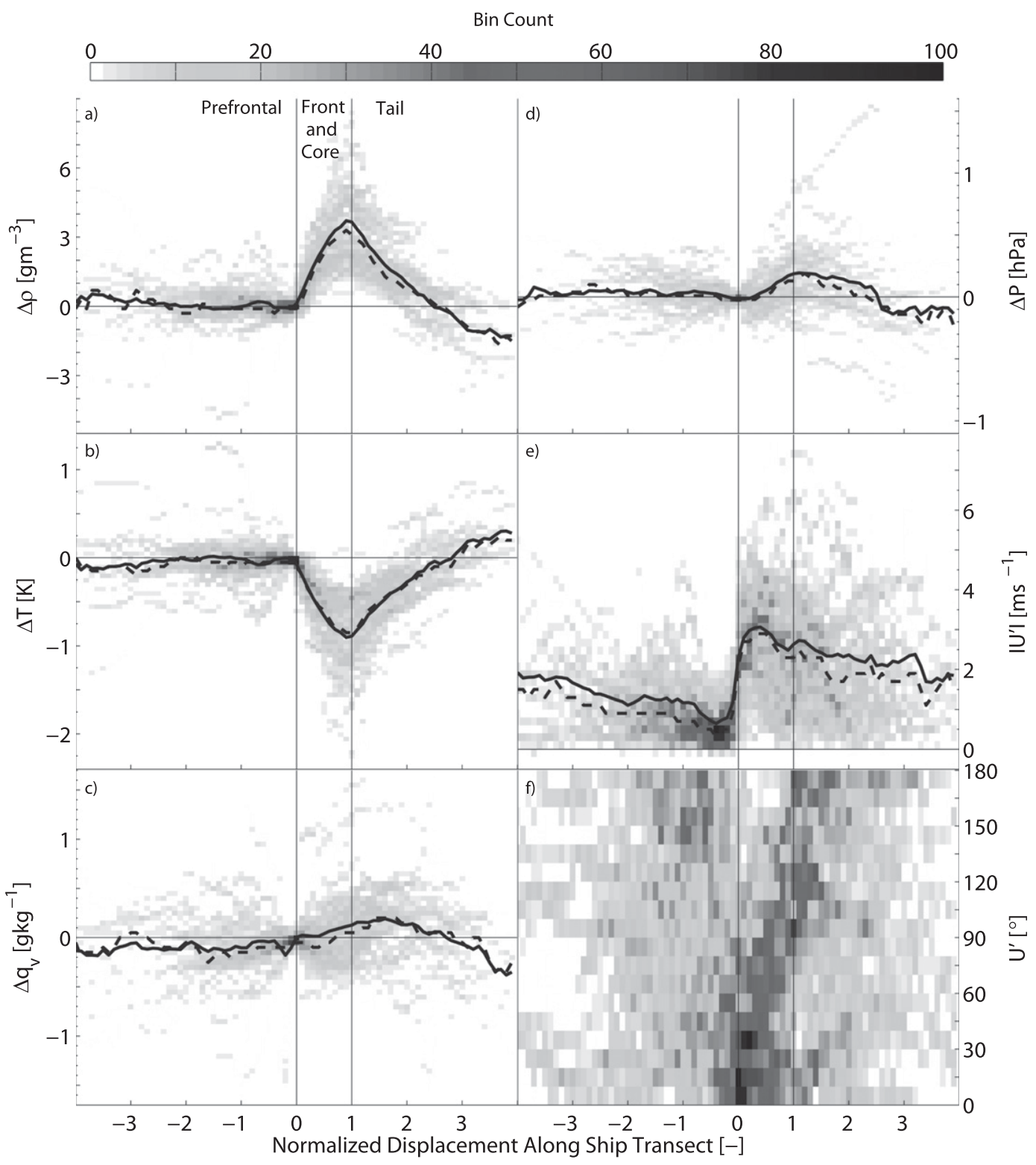

FIG. 6. Perturbation in ship (a) $\rho$, (b) $T$, (c) $q_{v}$, (d) air pressure $(P)$, (e) wind anomaly magnitude $\left(\left|U^{\prime}\right|\right)$, and (f) wind anomaly angular deviation $\left(U^{\prime}\right)$. Perturbations in (a)-(d) are measured with respect to the value at the start of each density current at $x=0$. Data are plotted along time-integrated ship transects before $(x<0)$ and during $(x \geq 0)$ the passage of all density currents detected by our method. Data from the ship time series are interpolated over a displacement axis using the ship-relative winds to create the individual time-integrated ship transects. The locations of data points along the time-integrated ship transect are then divided by the length of the combined density current front and core, subsequently located between $x=0$ and $x=1$. The solid (dashed) black lines in (a) $-(\mathrm{e})$ indicate the mean (median) value for each data point along $x$. Wind anomaly angular deviation in (f) is the absolute value of the smallest angle between the wind anomaly and the 10-min average prefrontal wind (i.e., correcting reflex and negative angles between the two vectors).

levels are between 2 and 4 times longer than the combined front and core zones that preceded them. The increase in temperature within these tail zones beyond prefrontal levels was also observed at night, when solar warming was not present. Within tails that extend for more than 3 times the combined front and core distance (data points at $x>3$ in Fig. 6b), temperature often continues to increase to above prefrontal levels. Although the cause of the continued warming in the tail zone is not certain, its magnitude $(<1 \mathrm{~K})$ is consistent with the mixing down of higher potential temperature air often observed in the subcloud mixed layer (Nicholls 
and Leighton 1986; see also section 3g) within less coupled boundary layers (Jones et al. 2011).

The $q_{v}$ across time-integrated ship transects of density currents has considerable variability but increases slightly on average (Fig. 6c). The peak in mean $q_{v}\left(\approx 0.4 \mathrm{~g} \mathrm{~kg}^{-1}\right)$ occurs well within the tail zone, where the temperature has significantly rebounded from the temperature minimum in the front and core. The pressure perturbation (Fig. 6d) across density currents also shows considerable variability across the time-integrated ship transect, which is likely due to the fact that the density currents occur in a nonquiescent, nonuniform background environment. The hydrostatic high that we expect to see in the core of the density current (Wakimoto 1982) nonetheless manifests in the mean of the perturbations $(\approx 0.2 \mathrm{hPa})$.

The magnitude of measured wind anomalies (Fig. 6e) increase in response to density and pressure perturbations associated with density currents. The mean wind anomaly magnitude peaks just inside the frontal zone at $\approx 2 \mathrm{~m} \mathrm{~s}^{-1}$. The maximum wind shift straddles the frontal boundary, which is consistent with previous surface observations of maximum wind convergence centered along gust front leading edges (Charba 1974; Wakimoto 1982). The gradual slackening of the mean wind anomaly across the core and tail zones is consistent with the gradual gradient in mean air density (Fig. 6a).

We examine wind anomaly direction in terms of angular deviation, which we define as the smaller angle formed between the wind anomaly and the 10-min average prefrontal base state wind. For example, an angular deviation of $180^{\circ}$ indicates a wind anomaly pointing in the opposite direction of the prefrontal wind, and an angular deviation of $90^{\circ}$ indicates an orthogonal wind anomaly. The mode of the angular deviation distribution is less than $60^{\circ}$ in the front zone of density currents (Fig. 6f). Wind anomalies opposite the prefrontal wind direction were almost never observed in the front zone. Density currents first encountered the ship either along the direction of the mean wind or approximately orthogonal to it. This fact was confirmed in the Doppler lidar data (Figs. 3-5). Moving farther into density currents, the mode of the distribution of angular deviation from the prefrontal wind transitioned steadily to approximately orthogonal $\left(\approx 90^{\circ}\right)$ by the end of the core zone $(x \approx 1)$ and to opposite $\left(\approx 180^{\circ}\right)$ inside the tail zone $(x \approx 2$; Fig. $6 \mathrm{f})$. This pattern is consistent with divergent flow except within extended tail zones $(x>2)$, where the angular deviation is highly variable.

\section{d. Wind profiles through density currents}

The density currents presented in this study are shallow $(\bar{h}=330 \mathrm{~m})$ and weak $\left(\overline{T_{\text {front }}+\text { core }}=0.52 \mathrm{~K}\right.$; average
$\overline{U_{\text {frontzone }}^{\prime}}=1.8 \mathrm{~m} \mathrm{~s}^{-1}$ ) compared to typical deep convective cold pools (e.g., Charba 1974; Goff 1976; Houze 1977; Zipser 1977; Gamache and Houze 1982; Wakimoto 1982; Wilson and Schreiber 1986; Droegemeier and Wilhelmson 1987; Mahoney 1988; Engerer et al. 2008). The depths of the surface layer and cold pools are similar $[\approx(200-300) \mathrm{m}]$; thus, the dynamics of the surface layer play a comparatively larger role in cold pool structure and evolution than for deep convective cold pools. The shallow depth and the weak temperature perturbation imply that the turbulent kinetic energy required to irreversibly mix out negatively buoyant density currents is comparatively small.

Figure 7 shows mean profiles of wind speed in the lowest $1200 \mathrm{~m}$ derived from lidar VADs. As shown in de Szoeke et al. (2012), ambient wind speeds are highest west of $85^{\circ} \mathrm{W}$. East of $85^{\circ} \mathrm{W}$, the change in wind speed with height is stronger in the lowest $200 \mathrm{~m}\left(\Delta U \approx 0.8 \mathrm{~m} \mathrm{~s}^{-1}\right)$, compared to the layer between 200 and $1200 \mathrm{~m}$. Wind speed profiles in prefrontal, front/core, and tail zones of density currents show only a weak longitudinal variations and are combined in Fig. 7. Stronger winds are associated with rain in the radar domain. East of $80^{\circ} \mathrm{W}$, wind speeds are about $2 \mathrm{~m} \mathrm{~s}^{-1}$ stronger on average when conditional rain rates exceeded $0.1 \mathrm{~mm} \mathrm{day}^{-1}$ between 25 and $60 \mathrm{~km}$ range from the ship (not shown).

Immediately prior to and within density currents, the change in mean wind within the lowest $200 \mathrm{~m}$ is larger than the ambient value $\left(\Delta U \approx 1.0-1.7 \mathrm{~m} \mathrm{~s}^{-1}\right)$. Above the tail zone, wind speeds peak at about $650 \mathrm{~m}$ altitude compared to $200 \mathrm{~m}$ for the front/core zone. Table 2 shows the mean values of speed shear from the surface layer to the midboundary layer (650-m layer) and from the surface layer to the cloud layer $(100 \mathrm{~m}$ above cloud base). The prefrontal zone (our proxy for environmental shear in the vicinity of density currents) shows consistent positive shear with height $\left(\overline{\partial U / \partial z}=1.7 \mathrm{~m} \mathrm{~s}^{-1} \mathrm{~km}^{-1}\right.$ between the surface and $100 \mathrm{~m}$ above the cloud base). On the scale of the density currents themselves, the wind profiles from the surface to $650-\mathrm{m}$ layer exhibit more average speed shear in the tail zone $\left(3.2 \mathrm{~m} \mathrm{~s}^{-1} \mathrm{~km}^{-1}\right)$ than in the front and core zones $\left(0.2 \mathrm{~m} \mathrm{~s}^{-1} \mathrm{~km}^{-1}\right)$. This is a function of the mapping of the directional shear onto the speed shear. Hence, although the magnitude of wind perturbations generated by density currents are strongest in the front and core zone (see Fig. 6), speed shear is strongest in the tail.

The dynamic and kinematic consequences of environmental speed shear may help explain the uninterrupted and gradual decline in density seen along time-integrated ship transects through tail zones (Fig. 6). The dynamic effect of the tail propagating against the environmental shear vector can reduce propagation speed and head 


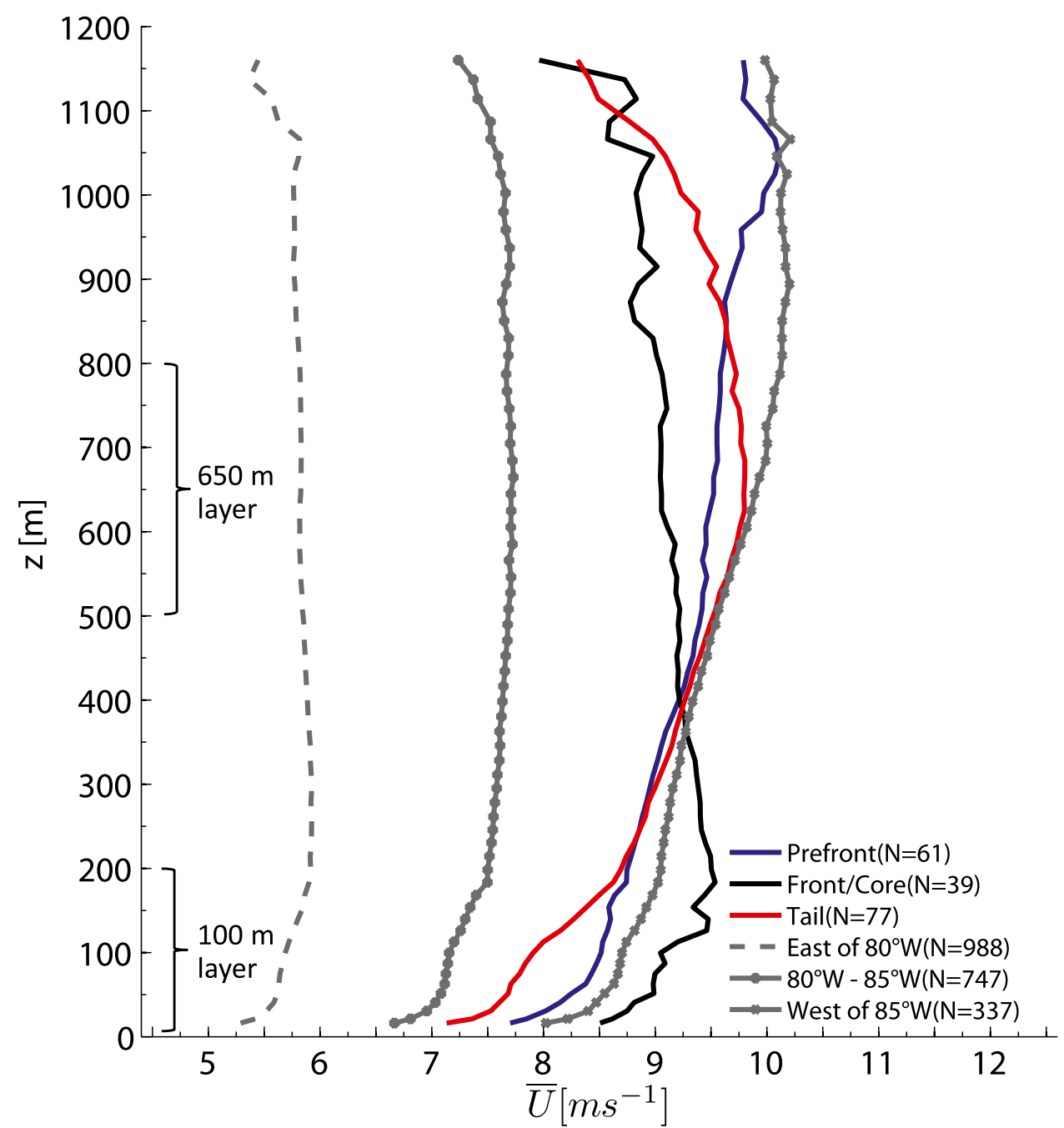

FIG. 7. Average lidar VAD wind speed profiles obtained within density current pre-front-core and tail zones compared with all VADs obtained in three different longitude categories (east of $80^{\circ} \mathrm{W}, 80^{\circ}-85^{\circ} \mathrm{W}$, and west of $85^{\circ} \mathrm{W}$ ); $N$ indicates the number of VADs that were averaged for each profile. Height-average standard deviation $(\sigma)$ is $2.20 \mathrm{~m} \mathrm{~s}^{-1}$ east of $80^{\circ} \mathrm{W}, 2.31 \mathrm{~m} \mathrm{~s}^{-1}$ from $80^{\circ}$ to $85^{\circ} \mathrm{W}$, and $2.23 \mathrm{~m} \mathrm{~s}^{-1}$ west of $85^{\circ} \mathrm{W}$. Layers over which mean shear values were calculated in Table 2 are marked with brackets.

depth compared to front and core zones (Chen 1995; Liu and Moncrieff 1996; Ross 2000). Furthermore, higher shear in the tail zone may increase sheardriven entrainment and diffusion of horizontal density gradients through enhanced turbulent mixing (Linden and Simpson 1986; Hallworth et al. 1996; Harichandran 2001).

Positive prefrontal speed shear $\left(\overline{\partial U / \partial z}=1.7 \mathrm{~m} \mathrm{~s}^{-1} \mathrm{~km}^{-1}\right)$ implies that the cloud level advects faster than the surface layer along the axis of the mean wind. Prefrontal cloud-base heights are on average $1190 \mathrm{~m}$, and wind speeds in the cloud layer are on average higher than in the surface layer $\left(\Delta U=1.9 \mathrm{~m} \mathrm{~s}^{-1}\right)$. The difference in mean wind speeds between the cloud layer and the surface layer is approximately the magnitude of the resultant wind perturbations found in density current front zones (Table 1 ). This observation supports the idea that the drizzle cell is approximately keeping up with its cold pool rather than the cold pool racing ahead (Wilson and Megenhardt 1997). The shear between the surface layer and the cloud layer has been neglected in previous studies (Stevens et al. 2005; Wang et al. 2010; Feingold et al. 2010; Wood et al. 2011b; Terai and Wood 2013).

Figure 8 graphically summarizes the kinematic explanation for the observed elongation of cold pools along the mean wind due to environmental speed shear. For simplicity, we do not include the dynamic effects caused by vertical shear through the depth of the cold 
TABLE 2. Mean speed shear $\left(\overline{\partial U / \partial z}\right.$, in units of $\left.\mathrm{m} \mathrm{s}^{-1} \mathrm{~km}^{-1}\right)$ measured by lidar VAD profiles between the surface layer and a layer centered at $650 \mathrm{~m}$ (between 500 and $800 \mathrm{~m}$ altitude) and between the surface layer and a layer centered $100 \mathrm{~m}$ above cloud base (between cloud base and $200 \mathrm{~m}$ above cloud base). The surface layer is defined as the layer average between $0 \mathrm{~m}$ and $200 \mathrm{~m}$ altitude (see Fig. 7). The number of VAD profiles $(N)$ used to calculate the mean values are shown in parentheses. Because of lidar beam attenuation by cloud droplets and hydrometeors, data centered $100 \mathrm{~m}$ above cloud base (variable altitude) were only used if velocities from more than four range gates (approximately half) were retrieved.

\begin{tabular}{ccccc}
\hline \hline \multirow{2}{*}{ Layer } & \multicolumn{3}{c}{ Density current } & \\
\cline { 2 - 4 } & Pre-front & Front-core & Tail & \multirow{2}{*}{ All VAD } \\
\hline $650 \mathrm{~m}$ & $2.1(61)$ & $0.2(39)$ & $3.2(76)$ & $0.8(2035)$ \\
$100 \mathrm{~m}$ above & $1.7(24)$ & $-0.5(18)$ & $0.0(34)$ & $0.2(552)$ \\
$\quad$ cloud base & & & & \\
\hline
\end{tabular}

pool. In this example, the source drizzle cell propagates along the shear vector at a constant rate marginally higher than the average of the time-varying cold pool propagation speed. The cold pool is released just prior to $t_{0}$ and propagates outward from the source drizzle cell $\left(t_{0}\right)$. Because the cold pool volume is finite, over time $\left(t_{1}, t_{2}\right.$, and $\left.t_{3}\right)$ it progressively expands more slowly because of the combined effects of spreading and turbulent dissipation and entrainment. The source drizzle cell moves northwest and begins to overtake the leading edge of the cold pool by $t_{2}$. Subsequent cold pools released by the source drizzle cell $\left(t_{3}\right)$ are therefore located down the shear vector. In this way, source drizzle cells leave behind their previously deposited cold pools to form elongated density current tails.

\section{e. Prefrontal updrafts}

Vertically pointing lidar scans were available for 27 density currents. Time-height plots for 24 out of 25 of the density currents with updrafts are shown in Fig. 9. No prominent updrafts could be discerned for 2 of the 27 density currents. To account for the west-to-east gradient of decreasing boundary layer depth and increasing degree of coupling (Wood and Bretherton 2004; Leon et al. 2008; Zuidema et al. 2009; de Szoeke et al. 2012), panels are sorted by longitude from west $\left(\approx 85^{\circ} \mathrm{W}\right.$ in panel 1$)$ to east $\left(\approx 76^{\circ} \mathrm{W}\right.$ in panel 24$)$. The backscatter intensity data in Fig. 9 indicate that midboundary layer clouds were quite extensive and common just before and after density currents crossed the ship (e.g., panels 3, 4, 6, 7, 10, 11, 13, 15, and 20). Often these clouds manifest as a shelf cloud distinct in form (e.g., panels 3, 4, 8, 10, 13, and 14) from the sporadic scud regularly observed in less-coupled boundary layers (panel 1). Multiple cloud layers beneath the stratocumulus deck can also occur (e.g., panel 7, corresponding to the cloud photo in Fig. 3a). The observation of shelf clouds distinct from the overlying cloud deck means that the near-surface-based updrafts associated with these arc clouds are not reaching the altitude of the main cloud stratocumulus deck. The base of the stratocumulus deck sometimes descended by up to $300 \mathrm{~m}$ as the frontal zone approached (e.g., panels 1 and 22), and this effect was most obvious when subcloud cumulus were not extensive. Perhaps the stratocumulus deck lowered due to cooling and moistening of the boundary layer by precipitation in the region surrounding the density current front.

Examination of the vertical velocity data (Fig. 9) shows that updrafts were consistently observed immediately prior to and over top of each density current. The updrafts extended from the minimum range of the lidar $(180 \mathrm{~m})$ to between 450 and $1200 \mathrm{~m}$ in height (mean $\approx 800 \mathrm{~m}$ ). Clouds often attenuated the lidar signal at the tops of the updrafts, which limited the maximum height estimates in these cases. The updrafts showed some variations in overall shape, which indicate complexity in the duration and the altitudes over which the lifting progressed. For example, the updraft observed over the density current shown in panel 4 was less intense and lasted longer than the updraft observed in panel 13,

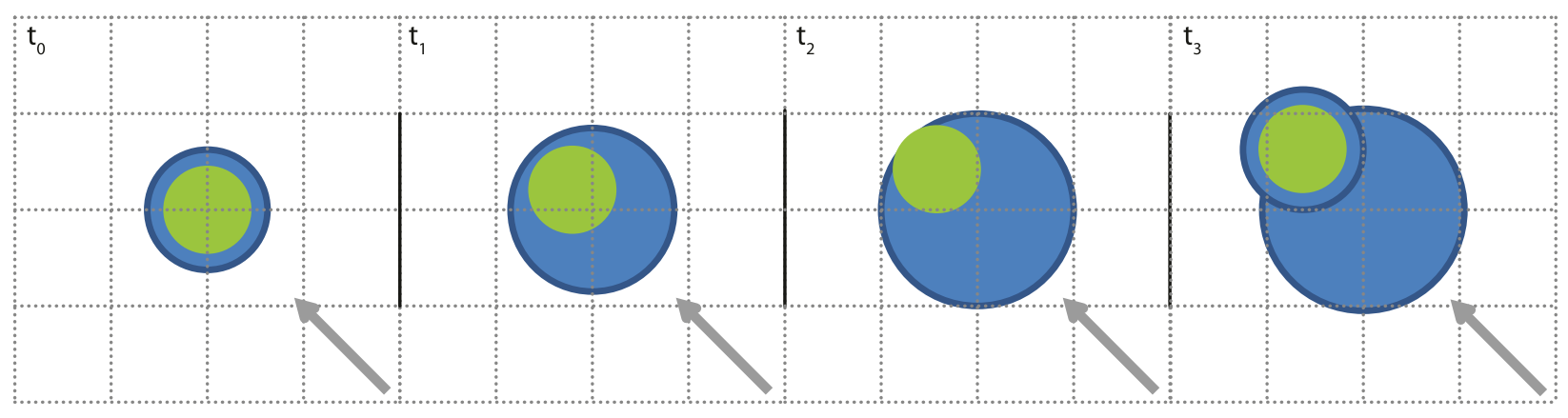

FIG. 8. Schematic of the development of a density current with an elongated tail oriented along the axis of the mean wind (gray arrow). Advection is shown relative to the prefrontal zone winds at the surface. The source drizzle cell (green) moves northwest at a marginally higher speed than the leading edge of the divergent cold pool (blue) in this depiction. Horizontal scale will vary with source drizzle cell size. 

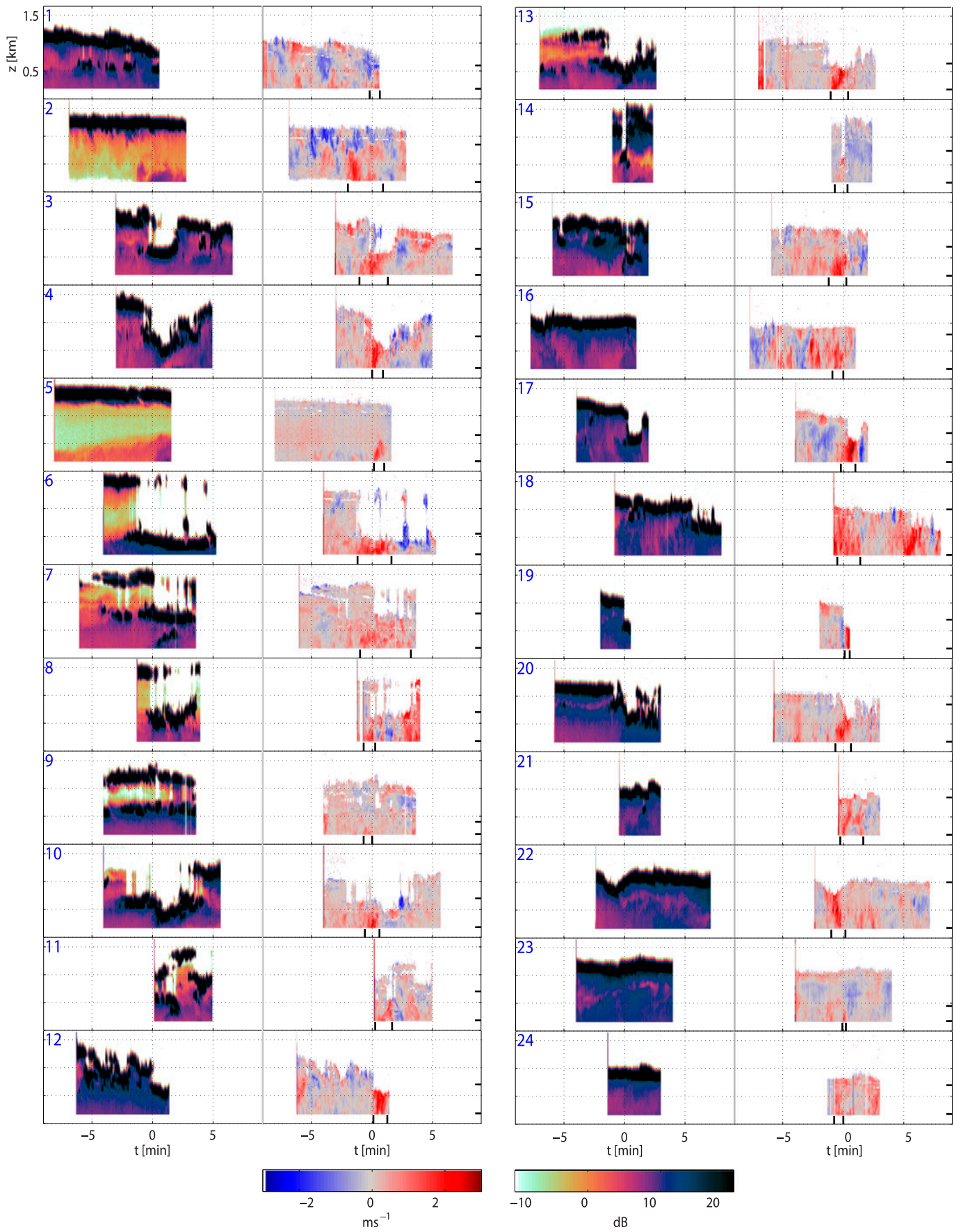

FIG. 9. Upward-pointing lidar images taken as density current fronts arrived over the ship at $x=0$ (1-min precision). Each panel (labeled 1 through 24) shows data acquired during the passage of a unique density current. The left sides of each panel show backscatter intensity and the right sides show $w$. Panels are sorted by longitude from west to east. All data available within \pm 9 min of the start of the front are shown for context. The vertical resolution of the lidar is $\approx 30 \mathrm{~m}$, and the horizontal resolution for the 2-Hz data varies according to ship-relative advection by the wind on the order of $1-10 \mathrm{~m}$. Backscatter intensity values above $20 \mathrm{~dB}$ (black) indicate cloud. Vertical velocities are red within updrafts and blue within downdrafts. Boundaries over which updraft statistics shown in Fig. 10 were calculated are marked with bold black tick marks in the vertical velocity plots (bottom and right on each). The density current associated with the cloud features shown in Fig. 3 is captured in panel 7, and the density current shown in Fig. 5 is captured in panel 23. 


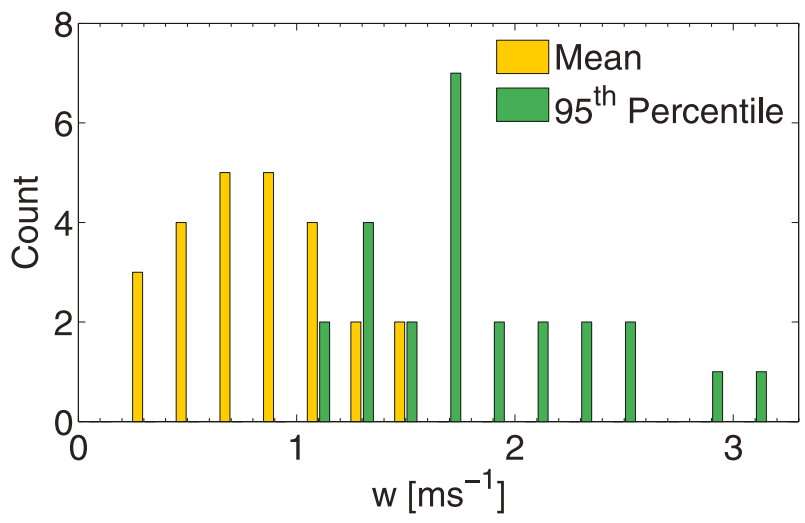

FIG. 10. Mean (gold) and 95th percentile (light green) vertical velocity $(w)$ measured by upward-pointing lidar for 25 prefrontal updrafts.

probably a consequence of the fact that the ship transected the front more obliquely in panel 4 . Additionally, many of the updrafts appear slanted over the density current (e.g., panels $4,5,15$, and 20), which is what we expect from a density current return circulation. The slanting of the updraft was stronger in some cases than others (e.g., panel 21 vs panel 17), which may indicate that prefrontal shear (Fig. 7) partially counteracted the rearward density current return circulation (Weisman and Rotunno 2004). Finally, in a few cases, the updraft along the frontal zone was not prominent (panels 1,8 , and 24).

Based on the Doppler lidar data, prefrontal average updraft vertical velocity ( $\bar{w}$; Fig. 10$)$ is $0.91 \mathrm{~m} \mathrm{~s}^{-1}$. Vertical velocities within the prefrontal updraft vary with height. The height of peak (95th percentile) updraft speed within the full depth of the updraft varied from 250 to $1200 \mathrm{~m}$ altitude with an average near $500 \mathrm{~m}$ altitude. Over the entire depth of the updrafts, peak $w$ varied between 1.1 and $3.1 \mathrm{~m} \mathrm{~s}^{-1}\left(\right.$ mean $\left.=1.9 \mathrm{~m} \mathrm{~s}^{-1}\right)$.

The lidar-measured updraft magnitudes are stronger than those obtained by Terai and Wood (2013) from composited flight anemometer data taken at $150 \mathrm{~m}$ altitude (their Fig. 12 shows maximum mean $w$ of $0.25 \mathrm{~m} \mathrm{~s}^{-1}$ ). The lidar provides information above $180 \mathrm{~m}$ altitude. In the layer from 180 to $200 \mathrm{~m}$, mean $w=0.67 \mathrm{~m} \mathrm{~s}^{-1}$ and peak updraft values varied from 0.4 to $2.4 \mathrm{~m} \mathrm{~s}^{-1}$. The $30-\mathrm{m}$ height difference between the lowest lidar measurement and the aircraft measurement cannot fully account for the difference in updraft speeds. Examination of Terai and Wood's (2013) Fig. 12 indicates that the composited updraft is inside the colder air behind the leading edge of the cold pool. It is not clear if their compositing method resolved the prefrontal updrafts that we observed in the Doppler lidar. Additionally, Terai and Wood (2013) note a background standard deviation for $w$ of $0.37 \mathrm{~m} \mathrm{~s}^{-1}$ in their

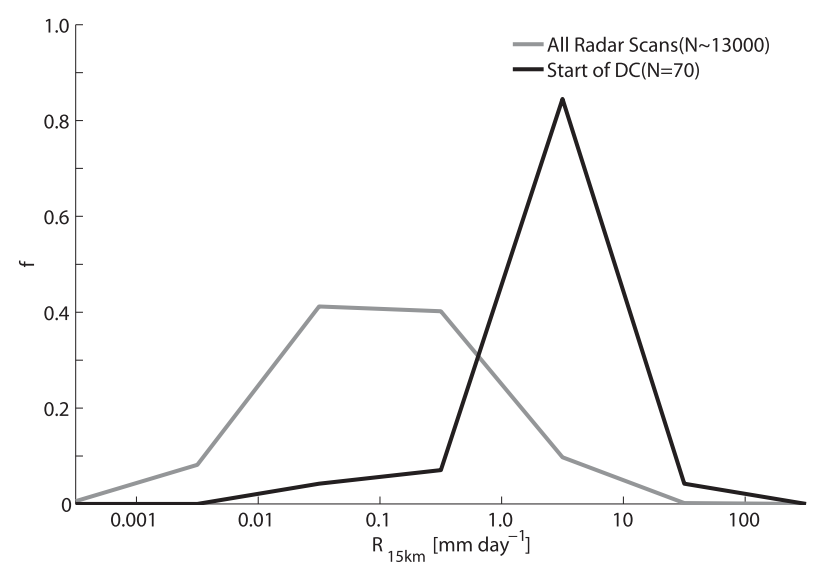

FIG. 11. Probability density function of C-band radar derived areal average rain rates within $15 \mathrm{~km}$ of the ship $\left(R_{15 \mathrm{~km}}\right)$. The distribution for all drizzle scenes throughout the 30-day dataset is shown in gray, and the distribution for drizzle scenes within 3 min of the start of a density current is shown in black.

1-Hz aircraft in situ data. This noise in the aircraft $w$ data is likely a contributing factor in the difference between the aircraft and lidar measurements of $w$.

\section{f. Proximity to drizzle}

Density currents were nearly always located near moderate and intense drizzle. Figure 11 shows the relative frequency distribution of areal average rain rates within $15 \mathrm{~km}$ of the ship $\left(R_{15 \mathrm{~km}}\right)$ for radar scans taken at the start of a density current compared with the distribution at all times during the cruise. The $15-\mathrm{km}$ maximum radius was selected as a trade-off. On the one hand, the $15-\mathrm{km}$ radius is large enough that it is likely to capture the specific drizzle cells capable of producing an outflow that reached the ship at the time of the radar scene. On the other hand, the radius is small enough that the increases in rain rate associated with these specific drizzle cells near the ship are not averaged out over too large of an area. Approximately $88 \%$ of drizzle scenes captured when a density current crossed the ship had $R_{15 \mathrm{~km}}>$ $1.0 \mathrm{~mm} \mathrm{day}^{-1}$. By comparison, only about $10 \%$ off all drizzle scenes met this criterion.

The distribution of radiometer-derived 1-min averaged column-integrated cloud liquid water path (LWP) sampled directly overhead before and during the passage of density currents over the ship is shown in Fig. 12. Conservative estimates of the minimum LWP threshold for heavy drizzle are $200 \mathrm{~g} \mathrm{~m}^{-2}$ (Bretherton et al. 2004; Miller and Yuter 2013). Only 10\% of LWPs collected over the entire cruise exceeded $200 \mathrm{~g} \mathrm{~m}^{-2}$ (cruise mean $=94 \mathrm{~g} \mathrm{~m}^{-2}$ ). When density currents were observed and LWP was available, the associated LWPs above $200 \mathrm{~g} \mathrm{~m}^{-2}$ occurred within $71 \%$ of the combined 


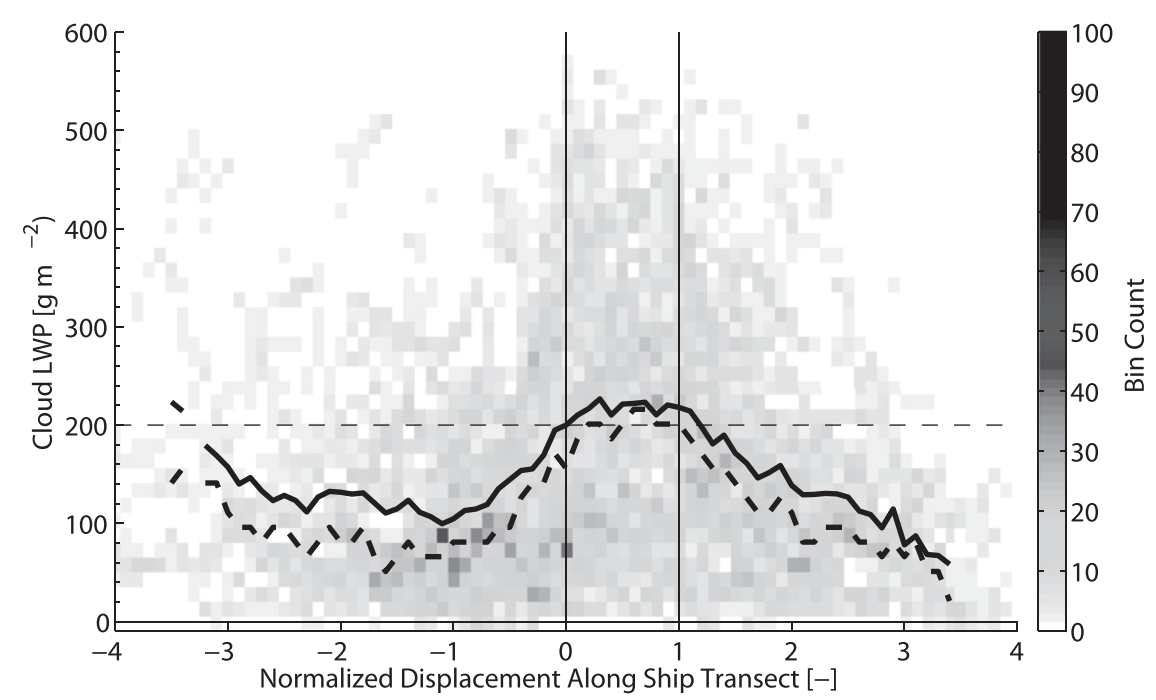

FIG. 12. Distributions of column-integrated cloud liquid water path (LWP) measured along time-integrated ship transects. The $x$ axis is displayed as in Fig. 6. Mean and median values are not shown if the number of data points within the bin falls below $1 / 10$ of the maximum value of any bin along the $x$ axis. Vertical lines at $x=0$ and $x=1$ mark the density current start and core end, as in Fig. 6 . The horizontal dashed line at $200 \mathrm{~g} \mathrm{~m}^{-2}$ marks the threshold of heavy drizzle.

front and core zones. However, an associated density current was observed only $25 \%$ of times with LWP > $200 \mathrm{~g} \mathrm{~m}^{-2}$. Areal average rain rate was a better predictor of density currents. Manual inspection of radar and lidar data indicates that the source drizzle cell was often nearby but did not pass directly over the ship (e.g., Fig. 3). Enhanced LWP in the vicinity of cold pools was also observed in Terai and Wood (2013).

\section{g. Relationship to the diurnal cycle}

The diurnal cycle of aggregated times when density currents were identified at the ship is shown alongside the diurnal cycle of enhanced local rain rates $\left(R_{15 \mathrm{~km}}>\right.$ $1.0 \mathrm{~mm} \mathrm{day}^{-1}$ ) in Fig. 13a. The east and west portions of the domain exhibit very similar diurnal cycles of precipitation, turbulent mixing, aerosol, and cloud depth

a)

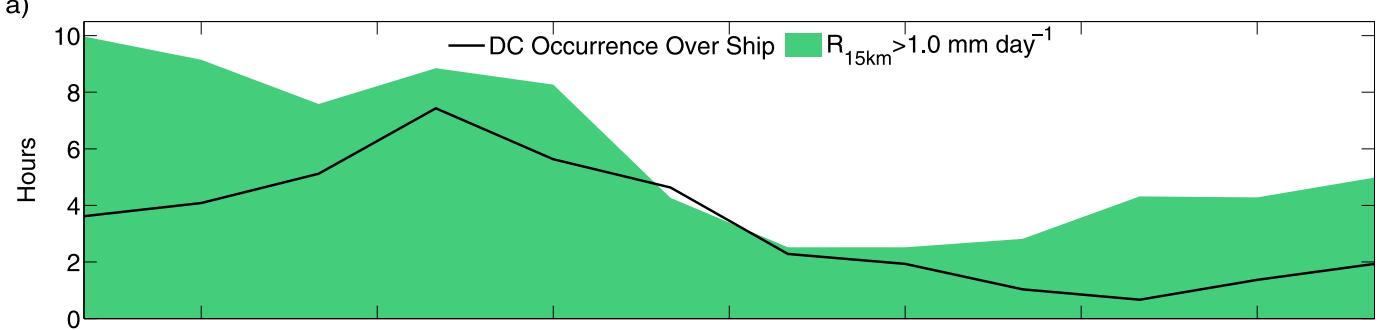

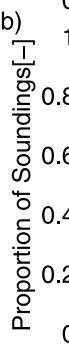

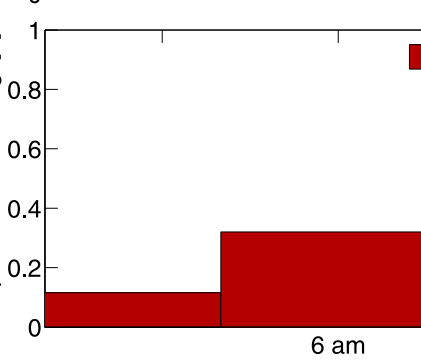

Dry Layer Occurrence

FIG. 13. (a) Diurnal cycle of occurrence of areal average rain rates within $15 \mathrm{~km}$ of the $\operatorname{ship}\left(R_{15 \mathrm{~km}}\right)>1.0 \mathrm{~mm} \mathrm{day}^{-1}$ (green) and times when a density current was detected over the ship (black line). Minutes when each condition is satisfied are assigned into the corresponding 2-h bin of local hour to produce the distributions. (b) Diurnal cycle of occurrence of 1 or more layers of dry air $(\mathrm{RH}<90 \%)$ in which RH decreases with height $(\partial \mathrm{RH} / \partial z>0)$ above $250-\mathrm{m}$ altitude in the 100-m averaged 4-h sounding data. The 8 soundings released within density currents are omitted, resulting in between 25 and 30 total soundings for each 4-h bin. 


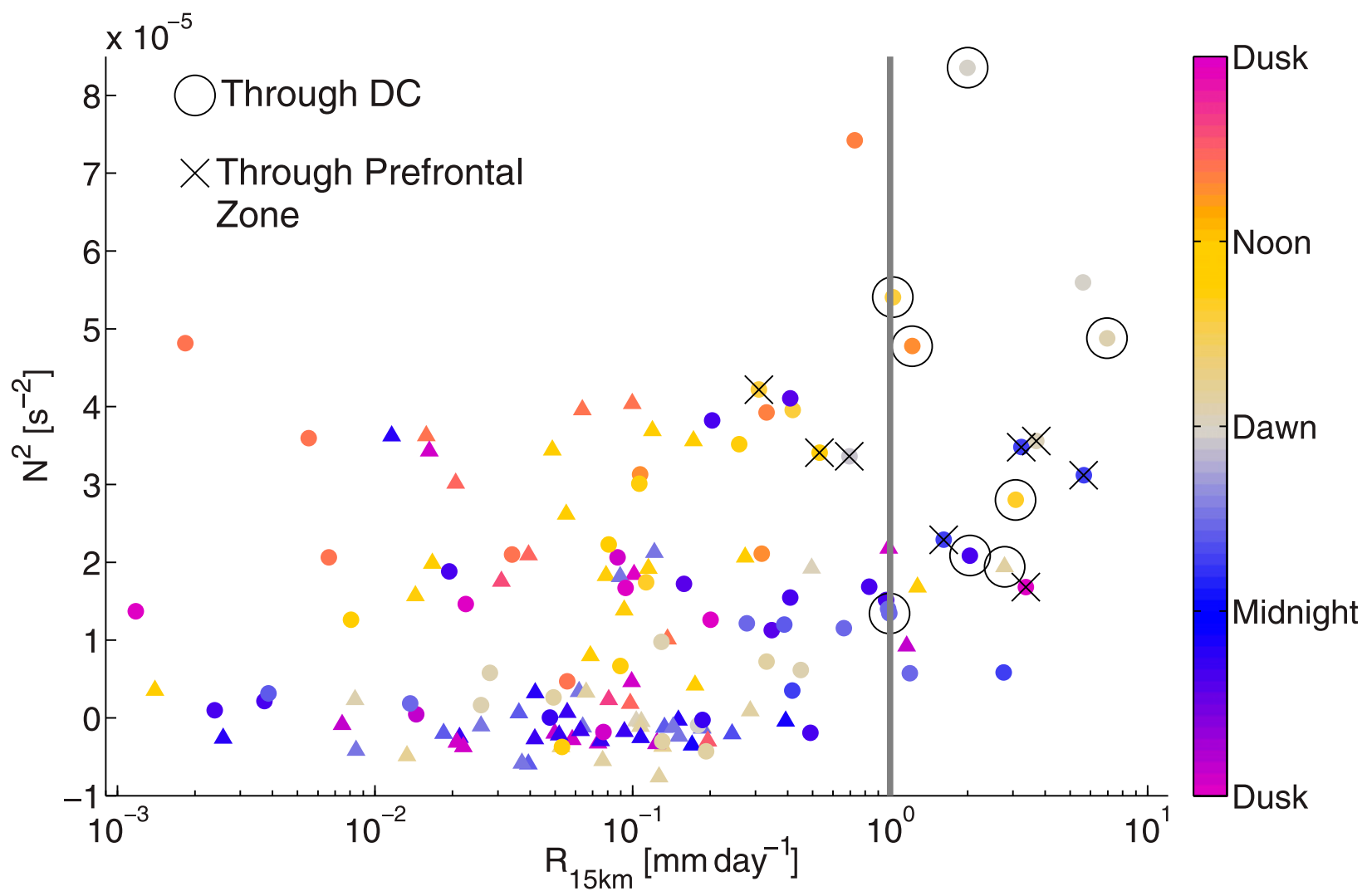

FIG. 14. Joint subcloud stability, time of day, and rain rate characteristics for periods with and without density currents. Data for all upper air soundings are shown, and the subsets of soundings through a density current (marked by an $\bigcirc$ symbol) and through a prefrontal zone within $30 \mathrm{~min}$ prior to start of density current (marked by an $\times$ symbol) are highlighted. Subcloud stability is quantified using the sounding-derived squared dry Brunt-Väisälä frequency $\left(N^{2}\right)$ calculated from the 100-m layer nearest the ocean surface to the 100-m layer just below the median cloud base. Color indicates local time of day. Data points collected east of $80^{\circ} \mathrm{W}$ are marked with triangles and points west of $80^{\circ} \mathrm{W}$ with circles. Enhanced local drizzle is defined as $R_{15 \mathrm{~km}}>1.0 \mathrm{~mm} \mathrm{day}^{-1}$ (right of vertical gray line).

(Burleyson et al. 2013). Density currents occurred throughout the diurnal cycle, although they were most frequent between 0000 and $1200 \mathrm{LT}$ and least frequent around sunset (1800 LT). The peak of the diurnal cycle of density current occurrence is after sunrise between 0600 and 0800 LT. Consistent with Burleyson et al.'s (2013) analysis that used estimated rain rates out to $60-\mathrm{km}$ range from the $R H B$, enhanced local rain rates peak overnight. Between 0000 and 0200 LT, when enhanced local rain rates are most frequent, density currents accompany them less than half of the time. Between 1000 and 1400 LT enhanced local rain rates and density currents occur at approximately equal frequencies. This pattern indicates that local drizzle is not a sufficient condition for density current formation, particularly at night, and that additional contributing factors to density current formation are most effective in the morning and afternoon.

One explanation for the preferential occurrence of density currents after sunrise is increasing boundary layer stability and reduced vertical mixing (Turton and Nicholls
1987; Burleyson et al. 2013). Figure 14 shows the diurnal trend in $R_{15 \mathrm{~km}}$ plotted against coincident sounding-derived squared dry Brunt-Väisälä frequency $\left(N^{2}\right)$. Stable conditions in the subcloud boundary layer are associated with two factors: daytime shortwave heating of the stratocumulus layer and enhanced local rain rates. The prefrontal environments of density currents and the environment within density currents are associated with more stable conditions $\left(N^{2}>1 \times 10^{-5} \mathrm{~s}^{-2}\right)$.

Subcloud stability can reduce the vertical transport of surface-based moisture up to the cloud deck, so it would tend to dry the subcloud mixed layer (e.g., Figs. 3c and $5 \mathrm{c})$. The drier air beneath the cloud base would more readily evaporate drizzle for a given rain rate and lead to stronger and more frequent density currents. The cloud base also begins to lift in the morning (Burleyson et al. 2013, their Fig. 7a) as solar stabilization sets in, which may further increase the amount of drizzle that evaporates. An additional explanation for the daytime peak in density currents is decreased boundary layer turbulence, which has been suggested to facilitate density current 


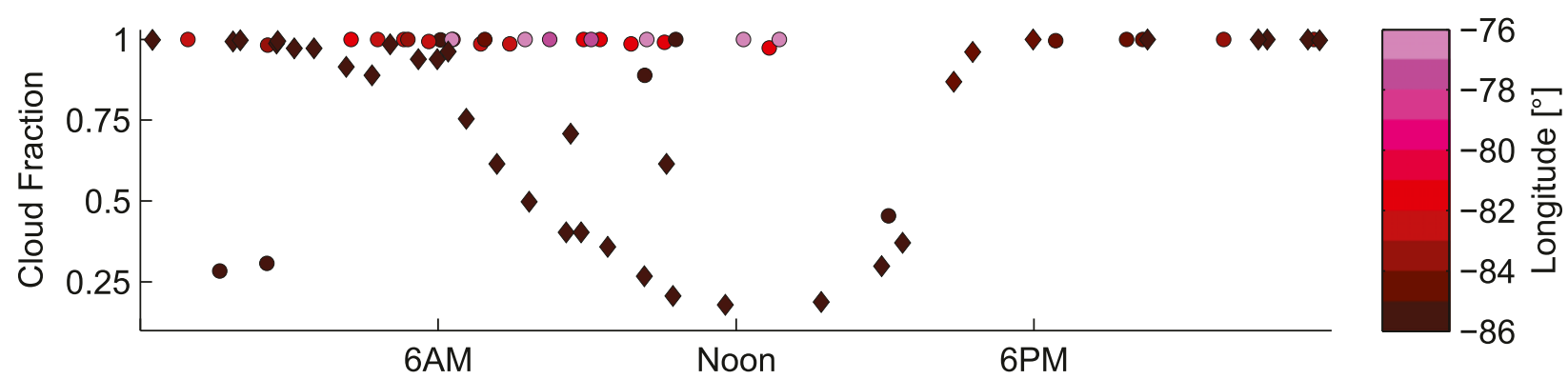

FIG. 15. The relationship among local time of day, longitude (color coded), and the most proximate half-hourly cloud fraction surrounding the ship at the start of each density current. The satellite-IR-derived cloud fraction data are averaged over a $1^{\circ} \times 1^{\circ}$ box centered on the ship and is available for 69 of the density currents. Data points corresponding to density currents occurring on 26 or 27 Oct 2008 are diamond-shaped. The remaining density currents are indicated by circles.

formation and increase density current lifetime (Linden and Simpson 1986).

Figure 13b depicts the diurnal cycle of the proportion of 100-m layer averaged soundings in which one or more dry layers of air $(\partial \mathrm{RH} / \partial z>0$ and $\mathrm{RH}<90 \%)$ were observed between $250 \mathrm{~m}$ and the median height of the cloud base. The minimum height of $250 \mathrm{~m}$ was selected to remove the small decrease in $\mathrm{RH}$ sometimes seen at the top of the slightly unstable surface layer (Nicholls and Leighton 1986; Stull 1988). RH values in the dry layers can be reduced by $10 \%$ or more compared to layers above and below. Of 161 soundings, 73 (45\%) had a dry layer. The eight soundings taken through density currents were omitted because the density currents themselves can create subcloud stable layers (six exhibited one or more dry layers). All eight prefrontal zone soundings had a dry layer. The dry layers are most common between 0900 and 1500 LT, approximately the same time when enhanced local drizzle is most likely to be accompanied by a density current (Fig. 13a). The dry layers were least common between 0000 and $0300 \mathrm{LT}$, when density currents were least likely to accompany enhanced local drizzle (Fig. 13a). This pattern supports the conclusion that drying of the subcloud layer may act in concert with enhanced local rain rates to form density currents.

Density currents were observed throughout the VOCALS-REx domain between $75^{\circ}$ and $86^{\circ} \mathrm{W}$ under both closed cell and open cell cloud fields (Fig. 15). Approximately $90 \%$ of density currents were sampled west of $80^{\circ} \mathrm{W}$, consistent with stronger and more frequent drizzle throughout the day compared to east of $80^{\circ} \mathrm{W}$ (Burleyson et al. 2013). Nearly half the density currents (34) were observed on 26-27 October 2008. During these 2 days, the ship was west of $84^{\circ} \mathrm{W}$ and the surrounding cloud field transitioned between nighttime closed cells and daytime open cells in a manner consistent with the overall diurnal cycle of cloud fraction decreasing after sunrise (0600 LT) and increasing starting about 1500 LT (Burleyson and Yuter 2015b). We determined mesoscale cloud organization using a combination of visual inspection of satellite images and objective determination of IR cloud fraction (see Figs. S1 and S2, and the animation in the online supplemental material). By contrast, the 15 density currents sampled over 7 days when the ship was east of $82^{\circ} \mathrm{W}$ occurred only between 0400 to 1300 LT under high cloud fraction conditions (greater than 0.97, indicating closed cells; see Figs. S1 and S2 in the online supplemental material).

\section{h. Vertical cross section of density current in a less coupled boundary layer}

We integrate observations from multiple instruments presented in this study with findings from previous work to create an idealized vertical cross section of a marine stratocumulus density current in Fig. 16. Soundingderived RH and $\theta_{v}$ in the prefrontal zone (left) are representative of a less coupled boundary layer. Moving up from the ocean surface, $\theta_{v}$ decreases in the surface layer up to $200 \mathrm{~m}$ altitude. Above the surface layer, $\theta_{v}$ levels off until it reaches a stable layer (here, $\approx 750 \mathrm{~m}$ altitude), which corresponds to the height of the surface mixed layer. Scud may form below the top of the surface mixed layer. Above the surface mixed layer is a layer that we have generically termed the "mixed layer" or the "subcloud mixed layer" (Nicholls and Leighton 1986, their Fig. 1). The mixed layer is separated from the surface mixed layer by the stability boundary and consequently is drier and cleaner. For this reason, there tends to be reduced lidar backscatter intensity within the mixed layer.

Mechanical lifting of prefrontal air caused by the stagnation point adjacent to the frontal zone of the density current is indicated by the large bent arrow in Fig. 16. Along and near the path of the lifted prefrontal air, extensive cloud formation is observed above the 


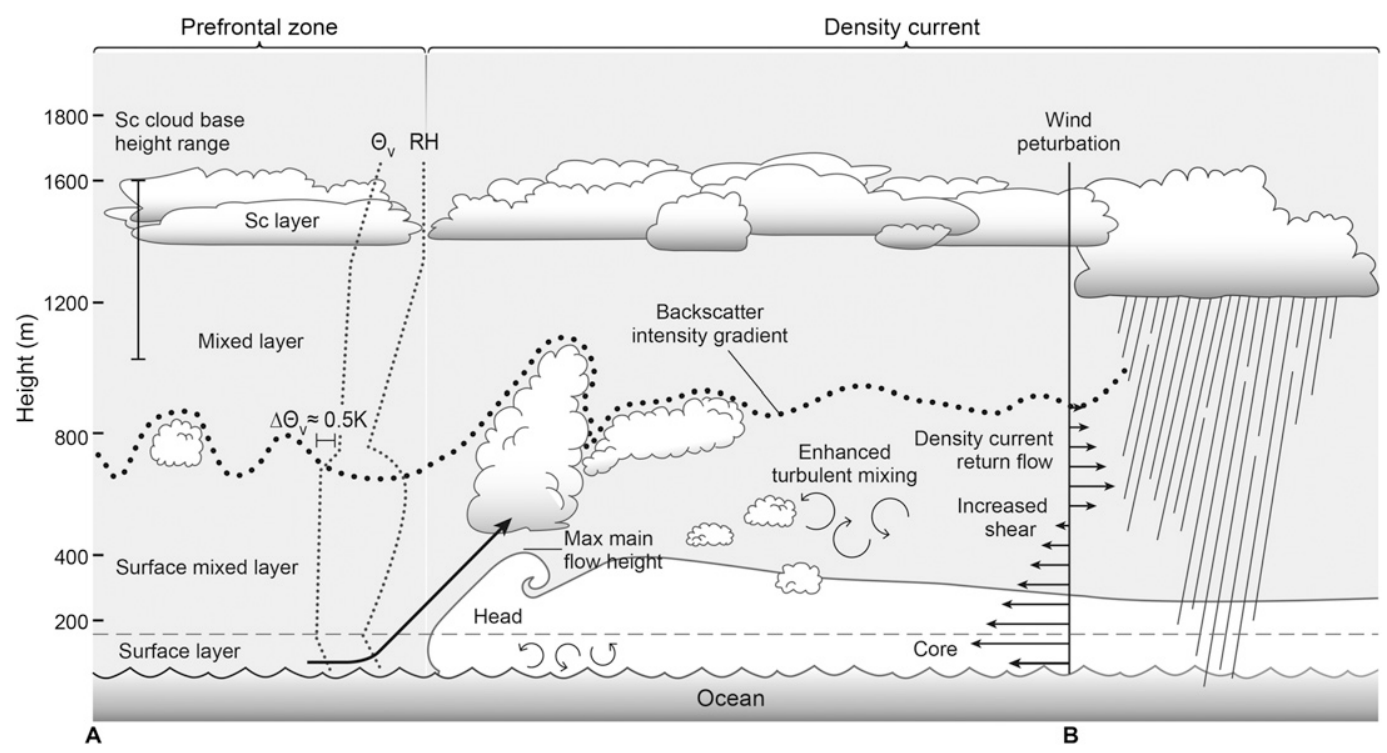

FIG. 16. Vertical cross section along the axis of propagation of an idealized drizzle-induced near-surface density current. The density current is traveling from right to left and is situated in a less coupled stratocumulus-topped marine boundary layer. In the prefrontal zone located to the left of the density current, the constituent layers are annotated. The dotted line indicates the height of the large decreasing vertical gradient in lidar backscatter intensity that marks the divide between the "mixed layer" and the surface mixed layer.

main density current flow. These clouds usually form shelves or arcs and may or may not extend to the base of the stratocumulus deck. The frontal zone slants backward with height up to the maximum depth of the flow ( $\approx 400 \mathrm{~m}$ ). Behind the head, the height of the main flow levels off and gradually descends. Consistent with lidar observations, some of the clouds behind and along the frontal zone are very low lying $(<400 \mathrm{~m})$.

The wind profile inside the density current is shown at $B$ in Fig. 16. Surface layer shear is present in the lowest $\approx 200 \mathrm{~m}$ of the main density current flow. The rightbound return flow (Simpson 1997; Droegemeier and Wilhelmson 1987, their Fig. 10; Simpson and Britter 1979, their Fig. 8 ) is located between $\approx 500$ and $\approx 800 \mathrm{~m}$ altitude in this example. Shear-generated turbulence can contribute over time to dissipate density current momentum and density gradients (Simpson and Britter 1979; Hallworth et al. 1996). The mixing may also transport moisture and aerosol upward. Parcels lifted by the turbulent motions may cool and approach saturation, causing hygroscopic growth of aerosol. The combined result of these effects is to extend the depth of the zone of increased lidar backscatter intensity through much of the shear layer (here, up to $\approx 900 \mathrm{~m}$ ).

\section{Conclusions}

In this study, we examine the bulk properties of 71 near-surface density currents found beneath drizzling stratocumuli in the SEP. The outflows were observed within a 30-day period using ship-based datasets collected during the VOCALS-REx campaign (de Szoeke et al. 2010; Wood et al. 2011a; de Szoeke et al. 2012; Mechoso et al. 2014). Previous observations of density currents in this domain are based on 150-m-altitude aircraft flight-level data (Terai and Wood 2013). Our analysis uses information from surface meteorological measurements, upper-air soundings, scanning Doppler lidar, scanning C-band radar, and satellite data. The leading edge of each outflow was identified by an air density increase greater than or equal to $1 \mathrm{~g} \mathrm{~m}^{-3}$ (equivalent to about $-0.24 \mathrm{~K}$ at constant $q_{v}$ ) using a $3.5-\mathrm{km}$ moving window average of 14-m air density. We also identified the subsequent core (peak density) and tail (dissipating) regions of the density current measured at the ship.

The observed density currents were 5-10 times thinner $(\bar{h}=330 \mathrm{~m})$ and weaker $\left(\overline{\Delta T}_{\text {front }+ \text { core }}=0.8 \mathrm{~K}\right)$ than typical continental thunderstorm cold pools (Bryan et al. 2007; Engerer et al. 2008). The density currents had maximum temperature depressions between 0.22 and $2.1 \mathrm{~K}$, depths of between 80 and $610 \mathrm{~m}$, and horizontal extents along time-integrated ship transects of 5-40 km. The observed frontal boundary propagation speed, lidar-observed near-surface kinematic structure, and ship-level temperature and pressure features are consistent with previous studies of density currents (Charba 1974; Wakimoto 1982; Simpson 1997; Haertel et al. 2001). Nearly $90 \%$ of density currents were associated with 
enhanced local drizzle $\left(R_{15 \mathrm{~km}}>1.0 \mathrm{~mm} \mathrm{day}^{-1}\right)$. Our prefrontal updraft intensities (peak $=1.1-3.1 \mathrm{~m} \mathrm{~s}^{-1}$; mean $=0.91 \mathrm{~m} \mathrm{~s}^{-1}$ ) and horizontal wind perturbations in the front zone $\left(\right.$ peak $=0.2-5.1 \mathrm{~m} \mathrm{~s}^{-1} ;$ mean $=1.8 \mathrm{~m} \mathrm{~s}^{-1}$ ) were larger than previous observational estimates (Terai and Wood 2013).

Key findings of this observational study are the following:

- Source drizzle cells and density current frontal boundaries approximately keep pace with each other because the differential speed of the cloud layer relative to the surface layer $\left(\overline{\Delta U}=1.9 \mathrm{~m} \mathrm{~s}^{-1}\right)$ is commensurate with the density current propagation speed $\left(\overline{U_{\text {frontzone }}^{\prime}}=1.8 \mathrm{~m} \mathrm{~s}^{-1}\right)$.

- Compared to front and core zones, density current tails have weaker density gradients, longer time-integrated ship transects, and less overhead drizzle. They exhibit stronger and consistently positive vertical shear of wind speed in the lowest $800 \mathrm{~m}$. The dynamic processes that characterize the tail zone appear to be distinct from those in the front and core zone.

- Prefrontal updrafts are present immediately prior to and over top of nearly every density current $(\bar{w}=$ $0.91 \mathrm{~m} \mathrm{~s}^{-1}$ ). Measured updrafts extend on average up to $800 \mathrm{~m}$ altitude.

- Shelf clouds surmounting the front edge of density currents frequently form. These shelf clouds may or may not connect to the overlying stratocumulus cloud deck.

- Density currents preferentially occur in a large region of predominantly open cells but also occur in regions of closed cells. In this study, approximately half (34) were observed west of $84^{\circ} \mathrm{W}$ on 26 and 27 October 2008 when closed cells overnight transitioned to open cellular clouds during the day.

- Density currents are not most frequent overnight when drizzle is most intense and extensive. Rather, density current frequency peaks after sunrise between 0600 and 0800 LT when drizzle cells are present within more stable prefrontal boundary layers containing one or more dry layers beneath the cloud base. The dry layers may contribute to density current formation by enhancing subcloud evaporation of drizzle.

The ship-based observations are direct evidence for cold pool-induced updrafts beneath drizzling marine stratocumuli. However, we did not see these updrafts routinely initiating new vigorous drizzle cells above them. This is not to say that cold pools make no contribution to mesoscale organization of marine stratocumulus. Rather, our observations suggest that cold pools are not the single or primary process controlling it. This observation is inconsistent with the hypothesis that cold pools drive the planform of clouds and precipitation in this region (Feingold et al. 2010). A clear case of convective initiation along an outflow collision boundary was captured ( $~ 0830$ UTC 26 October 2008 ) during the 2 VOCALS-REx RHB cruise legs. This case will be discussed in detail in a forthcoming paper.

Acknowledgments. Special thanks to Graham Feingold, Jan Kazil, Takanobu Yamaguchi, David Kingsmill, Tammy Weckwerth, David Mechem, Matthew Parker, Walter Robinson, and Robert Wood for their advice and technical support. We also thank Paquita Zuidema for providing the cloud liquid water path product used in this study. Beth Tully drafted some of the figures. This research was supported by the National Oceanic and Atmospheric Administration (NOAA) Climate Program Office (CPO) Climate Prediction Program for the Americas (CPPA) Grants GC09-252b and GC09-507, the Office of Science (Biological and Environmental Research) U.S. Department of Energy Grants DE-SC0006701 and DESC0006994, and the National Aeronautics and Space Administration Grant NNX11AE98G. The Pacific Northwest National Laboratory is operated for the Department of Energy by Battelle Memorial Institute under Contract DE-AC06-76RLO 1830.

\section{APPENDIX A}

\section{Characteristics of the NOAA Scanning Doppler Lidar Dataset}

The NOAA scanning high-resolution Doppler lidar transmits at a $2.022-\mu \mathrm{m}$ wavelength and is designed to accurately measure the radial velocity of light-scattering targets (primarily aerosols) along the beam path. The range gate spacing for independent velocity measurements is $30 \mathrm{~m}$. In addition to radial velocity, the instrument also records range-corrected backscatter intensity. Each range gate was sampled 100 times to create the $2-\mathrm{Hz}$ dataset. The data were collected to a maximum range of $8.3 \mathrm{~km}$, and backscattered signal intensities were adequate for detection out to 6 or $8 \mathrm{~km}$ in most of boundary layer scans observed. Very near-field data are unusable because of internal scattering within the lidar optical system, constraining the minimum range of the data to $180 \mathrm{~m}$ (Tucker et al. 2009). When operating with ample backscattered signal intensity and accurate platform motion correction, the HDRL radial velocity has been demonstrated to have better than $10 \mathrm{~cm} \mathrm{~s}^{-1}$ precision (Rye and Hardesty 1993). The Nyquist velocity ( $\pm 25 \mathrm{~m} \mathrm{~s}^{-1}$; Grund et al. 2001) suffices for 
unambiguous measurement of the $15-20 \mathrm{~m} \mathrm{~s}^{-1}$ maximum boundary layer winds measured by the surface meteorology sensors and rawinsondes during VOCALS-REx. Because aerosol particles have a negligible fall velocities compared to atmospheric motions, the measured velocities outside of clouds and regions of precipitation are assumed to be equivalent to the radial component of the wind. The high spatial, temporal, and velocity resolutions make HDRL data ideal for imaging turbulent motions and fine structure of mesoscale features below and between boundary layer clouds, where aerosol scatterers are generally abundant and signal attenuation due to clouds and drizzle is infrequent.

A GPS-based motion-compensation system enabled active pointing stabilization and removal of the ship's mean velocity in three dimensions from velocity measurements along the lidar's line of sight. This system provides better than $0.5^{\circ}$ beam-direction precision in heavy seas (Hill et al. 2008). To facilitate comparison with other data sources, each range gate was logged in world-fixed spherical coordinates.

Additional path-integrated constraints on HDRL signal intensity result when the lidar pulse encounters aerosols and hydrometeors in a turbulent environment. Signal attenuation due to absorption and scattering results in significant signal loss, especially in regions of clouds and precipitation. Because lidar pulses have a short wavelength, an additional concern is variations in backscatter signal intensity due to atmospheric refractive turbulence. Correction for changes in refractive turbulence or attenuation in the VOCAL-REx lidar data was not conducted.

\section{APPENDIX B}

\section{Estimating Density Current Propagation Speed}

For a Boussinesq fluid, the theoretical density current propagation speed is derived via energy conservation and is proportional to the strength of the density anomaly across the front and the flow depth. The Froude number $(\mathrm{Fr})$ is a dimensionless parameter that relates the estimated observed density current propagation speed ( $U^{\prime}$; see section $\left.3 \mathrm{~b}\right)$ to the propagation speed of a shallow water wave (corresponding to $\mathrm{Fr}=1$ ):

$$
\mathrm{Fr}=\frac{U^{\prime}}{\sqrt{g^{\prime} h}},
$$

where $g^{\prime}=g(\Delta \rho / \rho)$ is reduced gravity and $h$ is the density current depth. For this study, we derived $g^{\prime}$ from ship air density across the front and core of each density current. The $h$ estimate was obtained at the time (location) within the front and core zone that the lidar collected the
VAD and may not have been at the deepest point. Wakimoto (1982) states that $\mathrm{Fr} \approx 0.75$ is the accepted value for atmospheric density currents. Smaller Froude values were derived in studies of sea breeze fronts (Simpson 1969; $\overline{\mathrm{Fr}}=0.50$ ) and marine stratocumulus cold pools (Terai and Wood 2013; $\overline{\mathrm{Fr}}=0.53$ ).

We use two different measures of $U^{\prime}$ (see Table 1) to compare to the theoretical value: the mean magnitude of the wind anomaly inside density current front zones ( $\left.\overline{U_{\text {frontzone }}^{\prime}}\right)$ and the maximum strength of the wind anomaly inside density current front and core zones $\left(U_{\max }^{\prime}\right)$. Note that $U_{\max }^{\prime}$ is an overestimate. In addition to the main density current flow at the frontal boundary, $U_{\max }^{\prime}$ includes turbulent eddies and other smaller-scale flow perturbations present near the frontal boundary (Goff 1976). The use of $\overline{U^{\prime}}$ frontzone yields an average Froude number of $\overline{\mathrm{Fr}}=0.60(16 \mathrm{th}$ percentile $=0.27,84 \mathrm{th}$ percentile $=0.91)$ and $U_{\max }^{\prime}$ yields $\mathrm{Fr}=1.45$ (16th percentile $=1.06,84$ th percentile $=1.98$ ). The value of $\overline{U_{\text {frontzone }}}$ is the closer of the two estimates to the accepted value and is compared to boundary layer shear in section $3 d$. Given the uncertainties in both the estimates of height and propagation speed, our values are within reasonable bounds for diagnosing the observed density anomalies as density currents.

\section{REFERENCES}

Albrecht, B. A., M. P. Jensen, and W. J. Syrett, 1995: Marine boundary layer structure and fractional cloudiness. J. Geophys. Res., 100, 14 209-14 222, doi:10.1029/95JD00827.

Allen, G., and Coauthors, 2011: Southeast Pacific atmospheric composition and variability sampled along $20^{\circ} \mathrm{S}$ during VOCALS-REx. Atmos. Chem. Phys., 11, 5237-5262, doi:10.5194/acp-11-5237-2011.

Bates, T. S., and Coauthors, 2008: Boundary layer aerosol chemistry during TexAQS/GoMACCS 2006: Insights into aerosol sources and transformation processes. J. Geophys. Res., 113, D00F01, doi:10.1029/2008JD010023.

Berner, A. H., C. S. Bretherton, and R. Wood, 2011: Large-eddy simulation of mesoscale dynamics and entrainment around a pocket of open cells observed in VOCALS-REx RF06. Atmos. Chem. Phys., 11, 10 525-10 540, doi:10.5194/acp-11-10525-2011.

Bretherton, C. S., 1997: Convection in stratocumulus-capped atmospheric boundary layers. The Physics and Parameterization of Moist Atmospheric Convection, R. K. Smith, Ed., Kluwer, 127-142.

— and Coauthors, 2004: The EPIC 2001 stratocumulus study. Bull. Amer. Meteor. Soc., 85, 967-977, doi:10.1175/BAMS-85-7-967.

Browning, K. A., and R. Wexler, 1968: The determination of kinematic properties of a wind field using Doppler radar. J. Appl. Meteor., 7, 105-113, doi:10.1175/1520-0450(1968)007<0105: TDOKPO $>2.0 . \mathrm{CO} ; 2$.

Bryan, G. H., R. Rotunno, and J. M. Fritsch, 2007: Roll circulations in the convective region of a simulated squall line. J. Atmos. Sci., 64, 1249-1266, doi:10.1175/JAS3899.1.

Burleyson, C. D., and S. Yuter, 2015a: Patterns of diurnal marine stratocumulus cloud fraction variability. J. Appl. Meteor. Climatol., 54, 847-866, doi:10.1175/JAMC-D-14-0178.1. 
$\longrightarrow$, and $-2015 \mathrm{~b}$ : Subdiurnal stratocumulus cloud fraction variability and sensitivity to precipitation. J. Climate, 28, 29682985, doi:10.1175/JCLI-D-14-00648.1.

- S. P. de Szoeke, S. E. Yuter, M. Wilbanks, and W. A. Brewer, 2013: Ship-based observations of the diurnal cycle of southeast Pacific marine stratocumulus clouds and precipitation. J. Atmos. Sci., 70, 3876-3894, doi:10.1175/JAS-D-13-01.1.

Cairo, F., G. Di Donfrancesco, M. Snels, F. Fierli, M. Viterbini, S. Borrmann, and W. Frey, 2011: A comparison of light backscattering and particle size distribution measurements in tropical cirrus clouds. Atmos. Meas. Tech., 4, 557-570, doi:10.5194/ amt-4-557-2011.

Charba, J., 1974: Application of gravity current model to analysis of squall-line gust front. Mon. Wea. Rev., 102,140-156, doi:10.1175/ 1520-0493(1974)102<0140:AOGCMT>2.0.CO;2.

Chen, C., 1995: Numerical simulations of gravity currents in uniform shear flows. Mon. Wea. Rev., 123, 3240-3253, doi:10.1175/ 1520-0493(1995)123<3240:NSOGCI > 2.0.CO;2.

Colbo, K., and R. A. Weller, 2009: Accuracy of the IMET sensor package in the subtropics. J. Atmos. Oceanic Technol., 26, 1867-1890, doi:10.1175/2009JTECHO667.1.

Comstock, K. K., R. Wood, S. E. Yuter, and C. S. Bretherton, 2004: Reflectivity and rain rate in and below drizzling stratocumulus. Quart. J. Roy. Meteor. Soc., 130, 2891-2918, doi:10.1256/ qj.03.187.

—, C. S. Bretherton, and S. E. Yuter, 2005: Mesoscale variability and drizzle in southeast Pacific stratocumulus. J. Atmos. Sci., 62, 3792-3807, doi:10.1175/JAS3567.1.

— S. E. Yuter, R. Wood, and C. S. Bretherton, 2007: The threedimensional structure and kinematics of drizzling stratocumulus. Mon. Wea. Rev., 135, 3767-3784, doi:10.1175/ 2007MWR1944.1.

de Szoeke, S. P., C. W. Fairall, D. E. Wolfe, L. Bariteau, and P. Zuidema, 2010: Surface flux observations on the southeastern tropical Pacific ocean and attribution of SST errors in coupled ocean-atmosphere models. J. Climate, 23, 4152-4174, doi:10.1175/2010JCLI3411.1.

_ S. Yuter, D. Mechem, C. W. Fairall, C. D. Burleyson, and P. Zuidema, 2012: Observations of stratocumulus clouds and their effect on the eastern Pacific surface heat budget along $20^{\circ}$ S. J. Climate, 25, 8542-8567, doi:10.1175/JCLI-D-11-00618.1.

Droegemeier, K. K., and R. B. Wilhelmson, 1987: Numerical simulation of thunderstorm outflow dynamics. Part I: Outflow sensitivity experiments and turbulence dynamics. J. Atmos. Sci., 44, 1180-1210, doi:10.1175/1520-0469(1987)044<1180: NSOTOD $>2.0 . C O ; 2$

Engerer, N. A., D. J. Stensrud, and M. C. Coniglio, 2008: Surface characteristics of observed cold pools. Mon. Wea. Rev., 136, 4839-4849, doi:10.1175/2008MWR2528.1.

Feingold, G., and C. J. Grund, 1994: On the feasibility of using multi-wavelength lidar measurements to measure cloud condensation nuclei. J. Atmos. Oceanic Technol., 11, 1543-1558, doi:10.1175/1520-0426(1994)011<1543:FOUMLM>2.0.CO;2.

—, I. Koren, H. Wang, H. Xue, and W. A. Brewer, 2010: Precipitationgenerated oscillations in open cellular cloud fields. Nature, $\mathbf{4 6 6}$, 849-852, doi:10.1038/nature09314.

Gamache, J. F., and R. A. Houze, 1982: Mesoscale air motions associated with a tropical squall line. Mon. Wea. Rev., 110, 118-135, doi:10.1175/1520-0493(1982)110<0118: MAMAWA $>2.0 . \mathrm{CO} ; 2$.

Goff, R. C., 1976: Vertical structure of thunderstorm outflows. Mon. Wea. Rev., 104, 1429-1440, doi:10.1175/1520-0493(1976)104<1429: $\mathrm{VSOTO}>2.0 . \mathrm{CO} \cdot 2$
Grund, C. J., R. M. Banta, J. L. George, J. N. Howell, M. J. Post, R. A. Richter, and A. M. Weickmann, 2001: High-resolution Doppler lidar for boundary layer and cloud research. J. Atmos. Oceanic Technol., 18, 376-393, doi:10.1175/1520-0426(2001)018<0376: HRDLFB $>2.0 . \mathrm{CO} ; 2$.

Haertel, P. T., R. H. Johnson, and S. N. Tulich, 2001: Some simple simulations of thunderstorm outflows. J. Atmos. Sci., 58, 504-516, doi:10.1175/1520-0469(2001)058<0504: $\mathrm{SSSOTO}>2.0 . \mathrm{CO} ; 2$.

Hall, A. M., 2013: Lifecycle characteristics of marine stratocumulus precipitation in the southeast Pacific. M.S. thesis, Dept. of Marine, Earth, and Atmospheric Sciences, North Carolina State University, $78 \mathrm{pp}$. [Available online at http://repository. lib.ncsu.edu/ir/handle/1840.16/9307.]

Hallworth, M. A., H. E. Huppert, J. C. Phillips, and R. S. J. Sparks, 1996: Entrainment into two-dimensional and axisymmetric turbulent gravity currents. J. Fluid Mech., 308, 289-311, doi:10.1017/S0022112096001486.

Harichandran, P., 2001: Propagating gravity currents in a turbulent fluid. Doctoral thesis, University of Cambridge, $196 \mathrm{pp}$. [Available online at http://www.damtp.cam.ac.uk/lab/people/ sd/papers/Theses/.]

Harrison, S. J., J. R. Mecikalski, and K. R. Knupp, 2009: Analysis of outflow boundary collisions in north-central Alabama. Wea. Forecasting, 24, 1680-1690, doi:10.1175/2009WAF2222268.1.

Hill, R. J., W. A. Brewer, and S. C. Tucker, 2008: Platformmotion correction of velocity measured by Doppler lidar. J. Atmos. Oceanic Technol., 25, 1369-1382, doi:10.1175/ 2007JTECHA972.1.

Houze, R. A., 1977: Structure and dynamics of a tropical squall-line system. Mon. Wea. Rev., 105, 1540-1567, doi:10.1175/ 1520-0493(1977)105<1540:SADOAT $>2.0 . \mathrm{CO} ; 2$.

Intrieri, J. M., G. L. Stephens, W. L. Eberhard, and T. Uttal, 1993: A method for determining cirrus cloud particle sizes using lidar and radar backscatter technique. J. Appl. Meteor., 32, 1074-1082, doi:10.1175/1520-0450(1993)032<1074:AMFDCC >2.0.CO;2.

Jensen, J. B., S. Lee, P. B. Krummel, J. Katzfey, and D. Gogoasa, 2000: Precipitation in marine cumulus and stratocumulus. Part I: Thermodynamic and dynamic observations of closed cell circulations and cumulus bands. Atmos. Res., 54, 117-155, doi:10.1016/S0169-8095(00)00040-5.

Jones, C. R., C. S. Bretherton, and D. Leon, 2011: Coupled vs. decoupled boundary layers in VOCALS-REx. Atmos. Chem. Phys., 11, 7143-7153, doi:10.5194/acp-11-7143-2011.

Kazil, J., G. Feingold, H. Wang, and T. Yamaguchi, 2014: On the interaction between marine boundary layer cellular cloudiness and surface heat fluxes. Atmos. Chem. Phys., 14, 61-79, doi:10.5194/acp-14-61-2014.

Leon, D. C., Z. Wang, and D. Liu, 2008: Climatology of drizzle in marine boundary layer clouds based on 1 year of data from CloudSat and Cloud-Aerosol Lidar and Infrared Pathfinder Satellite Observations (CALIPSO). J. Geophys. Res., 113, D00A14, doi:10.1029/2008JD009835.

Lilly, D. K., 1968: Models of cloud-topped mixed layers under a strong inversion. Quart. J. Roy. Meteor. Soc., 94, 292-309, doi:10.1002/qj.49709440106.

Linden, P. F., and J. E. Simpson, 1986: Gravity-driven flows in a turbulent fluid. J. Fluid Mech., 172, 481-497, doi:10.1017/ S0022112086001829.

Liu, C., and M. W. Moncrieff, 1996: An analytical study of density currents in sheared, stratified fluids including the effects of latent heating. J. Atmos. Sci., 53, 3303-3312, doi:10.1175/ 1520-0469(1996)053<3303:AASODC>2.0.CO;2 
Mahoney, W. P., 1988: Gust front characteristics and the kinematics associated with interacting thunderstorm outflows. Mon. Wea. Rev., 116, 1474-1492, doi:10.1175/1520-0493(1988)116<1474: GFCATK $>2.0 . \mathrm{CO} ; 2$

Mechoso, C. R., and Coauthors, 2014: Ocean-cloud-atmosphere-land interactions in the southeastern Pacific: The VOCALS program. Bull. Amer. Meteor. Soc., 95, 357-375, doi:10.1175/BAMS-D-11-00246.1.

Miller, M. A., and S. E. Yuter, 2013: Detection and characterization of heavy drizzle cells within subtropical marine stratocumulus using AMSR-E 89-GHz passive microwave measurements. Atmos. Meas. Tech., 6, 1-13, doi:10.5194/amt-6-1-2013.

Nicholls, S., 1984: The dynamics of stratocumulus: Aircraft observations and comparisons with a mixed layer model. Quart. J. Roy. Meteor. Soc., 110, 783-820, doi:10.1002/ qj.49711046603.

—, and J. Leighton, 1986: An observational study of the structure of stratiform cloud sheets. Part I. Structure. Quart. J. Roy. Meteor. Soc., 112, 431-460, doi:10.1002/qj.49711247209.

Nucciarone, J. J., and G. S. Young, 1991: Aircraft measurements of turbulence spectra in the marine stratocumulus-topped boundary layer. J. Atmos. Sci., 48, 2382-2392, doi:10.1175/ 1520-0469(1991)048<2382:AMOTSI >2.0.CO;2.

Nuijens, L., B. Stevens, and A. P. Siebesma, 2009: The environment of precipitating shallow cumulus convection. J. Atmos. Sci., 66, 1962-1979, doi:10.1175/2008JAS2841.1.

Painemal, D., and P. Zuidema, 2011: Assessment of MODIS cloud effective radius and optical thickness retrievals over the southeast Pacific with VOCALS-REx in situ measurements. J. Geophys. Res., 116, D24206, doi:10.1029/2011JD016155.

Ross, A. N., 2000: Gravity currents on slopes. Doctoral thesis, University of Cambridge, $191 \mathrm{pp}$. [Available online at http:// www.damtp.cam.ac.uk/lab/people/sd/papers/Theses/.]

Ryan, M., M. J. Post, B. Martner, J. Novak, and L. Davis, 2002: The NOAA Ron Brown's shipboard Doppler precipitation radar. Sixth Symp. on Integrated Observing Systems, Orlando, FL, Amer. Meteor. Soc., P1.7. [Available online at https://ams. confex.com/ams/annual2002/techprogram/paper_27707.htm.]

Rye, B. J., and R. M. Hardesty, 1993: Discrete spectral peak estimation in incoherent backscatter heterodyne lidar. I. Spectral accumulation and the Cramer-Rao lower bound. IEEE Trans. Geosci. Remote Sens., 31, 16-27, doi:10.1109/36.210440.

Savic-Jovcic, V., and B. Stevens, 2008: The structure and mesoscale organization of precipitating stratocumulus. J. Atmos. Sci., $\mathbf{6 5}$, 1587-1605, doi:10.1175/2007JAS2456.1.

Seifert, A., and T. Heus, 2013: Large-eddy simulation of organized precipitating trade wind cumulus clouds. Atmos. Chem. Phys., 13, 5631-5645, doi:10.5194/acp-13-5631-2013.

Shank, L. M., and Coauthors, 2012: Organic matter and nonrefractory aerosol over the remote southeast Pacific: Oceanic and combustion sources. Atmos. Chem. Phys., 12, 557-576, doi:10.5194/acp-12-557-2012.

Simpson, J. E., 1969: A comparison between laboratory and atmospheric density currents. Quart. J. Roy. Meteor. Soc., 95, 758-765, doi:10.1002/qj.49709540609.

_ 1997: Gravity Currents: In the Environment and the Laboratory. 2nd ed. Cambridge University Press, 258 pp.

— , and R. E. Britter, 1979: The dynamics of the head of a gravity current advancing over a horizontal surface. J. Fluid Mech., 94, 477-495, doi:10.1017/S0022112079001142.

Snodgrass, E. R., L. Di Girolamo, and R. M. Rauber, 2009: Precipitation characteristics of trade wind clouds during RICO derived from radar, satellite, and aircraft measurements. J. Appl. Meteor. Climatol., 48, 464-483, doi:10.1175/2008JAMC1946.1.
Srivastava, R. C., 1987: A model of intense downdrafts driven by the melting and evaporation of precipitation. J. Atmos. Sci., 44, 1752-1774, doi:10.1175/1520-0469(1987)044<1752: AMOIDD $>2.0 . \mathrm{CO} ; 2$.

Stevens, B., 2000: Cloud transitions and decoupling in shear-free stratocumulus-topped boundary layers. Geophys. Res. Lett., 27, 2557-2560, doi:10.1029/1999GL011257.

, G. Vali, K. Comstock, R. Wood, M. C. Van Zanten, P. H. Austin, C. S. Bretherton, and D. H. Lenschow, 2005: Pockets of open cells and drizzle in marine stratocumulus. Bull. Amer. Meteor. Soc., 86, 51-57, doi:10.1175/BAMS-86-1-51.

Stull, R. B., 1988: An Introduction to Boundary Layer Meteorology. Kluwer/Springer, $666 \mathrm{pp}$.

Tang, I. N., 1996: Chemical and size effects of hygroscopic aerosols on light scattering coefficients. J. Geophys. Res., 101, 1924519250, doi:10.1029/96JD03003.

Terai, C. R., and R. Wood, 2013: Aircraft observations of cold pools under marine stratocumulus. Atmos. Chem. Phys., 13, 9899-9914, doi:10.5194/acp-13-9899-2013.

Tucker, S. C., C. J. Senff, A. M. Weickmann, W. A. Brewer, R. M Banta, S. P. Sandberg, D. C. Law, and R. M. Hardesty, 2009: Doppler lidar estimation of mixing height using turbulence, shear, and aerosol profiles. J. Atmos. Oceanic Technol., 26, 673-688, doi:10.1175/2008JTECHA1157.1.

Turton, J. D., and S. Nicholls, 1987: A study of the diurnal variation of stratocumulus using a multiple mixed layer model. Quart. J. Roy. Meteor. Soc., 113, 969-1009, doi:10.1002/qj.49711347712.

Wakimoto, R. M., 1982: The life cycle of thunderstorm gust fronts as viewed with Doppler radar and rawinsonde data. Mon. Wea. Rev., 110, 1060-1082, doi:10.1175/1520-0493(1982)110<1060 TLCOTG $>2.0 . \mathrm{CO} ; 2$.

— , and D. E. Kingsmill, 1995: Structure of an atmospheric undular bore generated from colliding boundaries during CaPE. Mon Wea. Rev., 123, 1374-1393, doi:10.1175/1520-0493(1995)123<1374: SOAAUB $>2.0 . \mathrm{CO} ; 2$.

Wang, H., and G. Feingold, 2009: Modeling mesoscale cellular structures and drizzle in marine stratocumulus. Part II: The microphysics and dynamics of the boundary region between open and closed cells. J. Atmos. Sci., 66, 3257-3275, doi:10.1175/2009JAS3120.1.

$\_,-1$, R. Wood, and J. Kazil, 2010: Modelling microphysical and meteorological controls on precipitation and cloud cellular structures in southeast Pacific stratocumulus. Atmos Chem. Phys., 10, 6347-6362, doi:10.5194/acp-10-6347-2010.

Warner, C., J. Simpson, D. W. Martin, D. Suchman, F. R. Mosher, and R. F. Reinking, 1979: Shallow convection on day 261 of GATE/mesoscale arcs. Mon. Wea. Rev., 107, 1617-1635, doi:10.1175/1520-0493(1979)107<1617:SCODOG >2.0.CO;2.

Weisman, M. L., and R. Rotunno, 2004: "A theory for strong longlived squall lines" revisited. J. Atmos. Sci., 61, 361-382, doi:10.1175/1520-0469(2004)061<0361:ATFSLS >2.0.CO;2.

Wilson, J. W., and W. E. Schreiber, 1986: Initiation of convective storms at radar-observed boundary-layer convergence lines. Mon. Wea. Rev., 114, 2516-2536, doi:10.1175/1520-0493(1986)114<2516: IOCSAR $>2.0 . \mathrm{CO} ; 2$.

_ , and D. L. Megenhardt, 1997: Thunderstorm initiation, organization, and lifetime associated with Florida boundary layer convergence lines. Mon. Wea. Rev., 125, 1507-1525, doi:10.1175/1520-0493(1997)125<1507:TIOALA > 2.0.CO;2.

Wood, R., and C. S. Bretherton, 2004: Boundary layer depth, entrainment, and decoupling in the cloud-capped subtropical and tropical marine boundary layer. J. Climate, 17, 3576-3588, doi:10.1175/1520-0442(2004)017<3576:BLDEAD>2.0.CO;2. 
and Coauthors, 2011a: The VAMOS Ocean-CloudAtmosphere-Land Study Regional Experiment (VOCALSREx): Goals, platforms, and field operations. Atmos. Chem. Phys., 11, 627-654, doi:10.5194/acp-11-627-2011.

C. S. Bretherton, D. Leon, A. D. Clarke, P. Zuidema, G. Allen, and H. Coe, 2011b: An aircraft case study of the spatial transition from closed to open mesoscale cellular convection over the southeast Pacific. Atmos. Chem. Phys., 11, 2341-2370, doi:10.5194/acp-11-2341-2011.
Zipser, E. J., 1977: Mesoscale and convective-scale downdrafts as distinct components of squall-line structure. Mon. Wea. Rev., 105, 1568-1589, doi:10.1175/1520-0493(1977)105<1568: MACDAD $>2.0 . \mathrm{CO} ; 2$.

Zuidema, P., and Coauthors, 2012: On trade wind cumulus cold pools. J. Atmos. Sci., 69, 258-280, doi:10.1175/JAS-D-11-0143.1. , D. Painemal, S. de Szoeke, and C. Fairall, 2009: Stratocumulus cloud-top height estimates and their climatic implications. J. Climate, 22, 4652-4666, doi:10.1175/2009JCLI2708.1. 